\title{
Geochemistry of the Amazcala Caldera, Querétaro, Mexico: An unusual peralkaline center in the central Mexican Volcanic Belt
}

\author{
Gerardo de Jesús Aguirre-Díaz, Ofelia Morton-Bermea
}

Gerardo de Jesús Aguirre-Díaz

ger@geociencias.unam.mx

Centro de Geociencias, Universidad

Nacional Autónoma de México, campus

UNAM-Juriquilla, Blvd. Juriquilla No. 3001,

Querétaro, Querétaro 76230, Mexico.

\section{Ofelia Morton-Bermea}

Instituto de Geofisica, Universidad Nacional Autónoma de México, Circuito de la Investigación Científica s/n, Ciudad Universitaria, Coyoacán 04150, CDMX, Mexico.

BOL. SOC. GEOL. MEX. 2018

VOL. 70 NO. 3

P. $731-760$

http://dx.doi.org/10.18268/BSGM2018v70n3a8

\begin{abstract}
The Amazcala caldera is $30 \mathrm{~km}$ northeast of Queretaro City, Mexico, in the central sector of the Mexican Volcanic Belt. It is $14 \times 11 \mathrm{~km}$ in size and was active from 7.3 to $6.6 \mathrm{Ma}$. The first caldera event was the Ezequiel Montes Pumice, which was a widespread grey pumice-fall sequence of coarse to fine lapilli, with thicknesses from $<1$ to $\sim 43 \mathrm{~m}$. Colón ignimbrite was next in the evolution of the caldera and consisted mostly of dense pyroclastic density current deposits interbedded with pumice-fall lapilli and minor dilute pyroclastic density current deposits. Several rhyolitic domes form the rim of the caldera, some of which have associated pumice fall and pyroclastic density current deposits. The rim domes still preserve aphyric obsidian, named as Rim Dome Obsidian. A 4 x 2 $\mathrm{km}$ intra-caldera lava dome represents the last caldera event, but lacks preserved obsidian. All caldera products are peralkaline rhyolites with chemical characteristics of comendites. A correction of $\mathrm{Na}_{\mathrm{O}} \mathrm{O}$ and $\mathrm{K}_{2} \mathrm{O}$ was necessary because of secondary hydration of glasses in pumice deposits. This correction process could also be applied in similar weathered or devitrified volcanic deposits at other localities. $\mathrm{Al}_{2} \mathrm{O}_{3}, \mathrm{~K}_{2} \mathrm{O}$ $\mathrm{Fe}_{2} \mathrm{O}_{3}$, and most REE (except $\mathrm{La}, \mathrm{Ce}$ ) and $\mathrm{Y}$ remain practically unchanged from the earliest caldera unit (Ezequiel Montes Pumice) to the last analyzed caldera unit (Rhyolitic Dome Obsidian), and $\mathrm{Ba}, \mathrm{Sr}$ La, $\mathrm{P}_{2} \mathrm{O}_{5}$ markedly decrease from Ezequiel Montes Pumice to Rhyolitic Dome Obsidia, whereas HFSE $\mathrm{Th}, \mathrm{Nb}, \mathrm{Zr}$, and $\mathrm{TiO}_{2}$ slightly increase from Ezequiel Montes Pumice to Rhyolitic Dome Obsidian; that is, from pre-caldera collapse to post-caldera collapse. Comparing Amazcala units with calc-alkaline mafic lavas of the area, either pre- or post-caldera, HFSE, REE, and Th are markedly enriched in the Amazcala caldera products. In contrast, $\mathrm{Ba}, \mathrm{Sr}_{2} \mathrm{P}_{2} \mathrm{O}_{5}$, and $\mathrm{TiO}$ are strongly depleted in the Amazcala units with respect to the mafic rocks. These data suggest a very efficient fractional crystallization process of possible parental mafic magmas. All caldera products are enriched in HFSE, LILE and REE, in particular Nb, $\mathrm{Th}, \mathrm{Zr}$ and REE, suggesting an input from the fertile mantle during a pulse of continental intra-arc extension in the central sector of the Mexican Volcanic Belt. Amazcala caldera comendites have simila chemical signatures than other caldera comendites at extensional settings within the western sector of the Mexican Volcanic Belt, and with comendites within continental rifts, such as the Kenya rift in Africa.
\end{abstract}

Keywords: caldera, comendite, peralkaline rhyolite, continental extension, Na-loss and K-enrichment correction.

\section{RESUMEN}

La caldera de Amazcala está ubicada a $30 \mathrm{~km}$ al NE de la Ciudad de Querétaro, México, en el sector central del Cinturón Volcánico Mexicano. Mide $14 \times 11 \mathrm{~km}$ y estuvo activa entre 7.3 y $6.6 \mathrm{Ma}$. El primer evento de la caldera fue la erupción de la Pómez Ezequiel Montes, que consiste en una secuencia de depósitos de caída de lapilli grueso a fino de pómez gris con amplia distribución y espesores de $<1$ a $\sim 43 \mathrm{~m}$. La ignimbrita Colón fue el siguiente evento en la evolución de la caldera y consiste sobre todo en depósitos de corrientes piroclásticas de densidad intercaladas con depósitos de caída de lapilli de pómez y de corrientes piroclásticas de densidad diluidos menores. Varios domos riolíticos forman el anillo de la caldera, algunos de ellos asociados a depósitos de caída de lapilli gruesos de pómez y de corrientes piroclásticas de densidad menores. Los domos del anillo aún conservan obsidiana afirica, roca que se denominó como Obsidiana de Domo del Anillo. El último evento de la caldera está representado por un gran domo de riolita intra-caldera de $4 \times 2$ $\mathrm{km}$, pero sin obsidiana preservada. Todos los productos de la caldera son riolitas hiperalcalinas con características químicas de comenditas. Fue necesario realizar una corrección de $\mathrm{Na}_{2} \mathrm{O}$ y $K_{2} \mathrm{O}$ por la hidratación secundaria en el vidrio de los depósitos de pómez. Esta corrección podría aplicarse en depósitos volcánicos similares, alterados o devitrificados de otros lugares. $\mathrm{Al}_{2} \mathrm{O}_{3}, \mathrm{~K}_{2} \mathrm{O}, \mathrm{Fe}_{2} \mathrm{O}_{3}$, y la mayoría de los $\mathrm{REE}$ (excepto $\mathrm{La}, \mathrm{Ce})$ e $\mathrm{Y}$ permanecen prácticamente sin cambio desde la primera unidad de la caldera (Pómez Ezequiel Montes) hasta la última unidad analizada (Domos de Obsidiana del Anillo), y $\mathrm{Ba}, \mathrm{Sr}, \mathrm{La}, \mathrm{P}_{2} \mathrm{O}_{5}$ se empobrecen notoriamente de Pómez Ezequiel Montes a Domos de Obsidiana del Anillo, es decir, de antes del colapso caldérico a después del colapso. Comparando las unidades de Amazcala con lavas máficas del área, ya sean pre-caldera o post-caldera, HFSE, REE $y$ Th están marcadamente enriquecidos en los productos de Amazcala. En contraste, $\mathrm{Ba}, \mathrm{Sr}, \mathrm{P}_{2} \mathrm{O}_{5}$ y $\mathrm{Ti}_{2} \mathrm{O}_{2}$ están fuertemente empobrecidos en las unidades de Amazcala con respecto a las rocas máficas. Estos datos sugieren un eficiente proceso de cristalización fraccionada de un posible magma parental máfico. Todos los productos de la caldera están enriquecidos en HFSE, LILE y REE, en particular Nb, Th, Zr y REE, sugiriendo una incorporación de magma proveniente del manto fértil durante un pulso de extensión intra-arco en el sector central del Cinturón Volcánico Mexicano. Las comenditas de la caldera de Amazcala poseen una firma química similar a la de comenditas de otras calderas en regímenes tectónicos extensionales en el Cinturón Volcánico Mexicano, y con comenditas de rift continentales como las del Rift de Kenia en África.

Palabras clave: caldera, comendita, riolita hiperalcalina, extension extensión continental, corrección por pérdida de Na y enriquecimiento de $K$. 


\section{Introduction}

The Amazcala caldera is located $30 \mathrm{~km}$ to the NE of Querétaro City, at the northern part of the Mexican Volcanic Belt (MVB; Figure 1). It is a 14 x 11 elliptical structure (Figure 2) that was active from 7.3 - 6.6 Ma ago (Aguirre-Díaz and LópezMartínez, 2001). The caldera is one of several calderas identified in the central sector of the MVB (Figure 1), including, from north to south, Apaseo (Aguirre-Díaz and López-Martínez, 2000), Los Agustinos (Aguirre-Díaz et al., 1998, 1999), Huichapan (Milán et al., 1993; Aguirre-Díaz and López-Martínez, 2009), Amealco (Sánchez-Rubio, 1978; Aguirre-Díaz, 1996, 2001a), and Los Azufres (Pradal and Robin, 1994) and Zitácuaro (Capra et al., 1997). At $480 \mathrm{~km}$ from the Middle America Trench, the Amazcala caldera is the farthest inland caldera in the central sector of the MVB. Its age at 7.3 - 6.6 Ma makes it the oldest caldera of this volcanic province so far reported.

This work focuses on the geochemical description of the Amazcala caldera products, and includes, for comparison, pre-caldera and post-caldera andesites and basalts of the Amazcala region. We emphasize the hyperalkaline nature of all caldera products and provide a plausible explanation about their source and emplacement in the central part of the MVB. The caldera was identified by Aguirre-Díaz and López-Martínez (2001) and this is the first time that a complete set of major and trace element geochemistry data for this volcanic center is reported. The peralkaline nature of the caldera products is an anomaly within the tectonic setting where the caldera was formed, both in space and time, within the central sector of the MVB, which is mostly calc-alkaline. The case of the Amazcala caldera is particularly noteworthy, with typical orogenic andesites and basalts just before and after the Amazcala caldera event.

\subsection{SUMMARY OF THE GEOLOGY OF THE AMAZGALA GALDERA}

The following summary is based on the work of Aguirre-Díaz and López-Martínez (2001). The geological map of the Amazcala caldera and stratigraphy are shown in Figure 3. All reported ages are ${ }^{40} \mathrm{Ar}-{ }^{39} \mathrm{Ar}$ analyses. The initial activity of the caldera occurred at about 7.3 Ma ago in the form of Plinian columns that formed the Ezequiel Montes Pumice (EMP), which is a widespread pumice fallout with two dispersal axes, one to the southwest and the other to southeast, accounting for a minimum dense rock equivalent (DRE) volume of $4.4 \mathrm{~km}^{3}$. Details of physical parameters of this large explosive event are described in Hernández et al. (2009). EMP was followed by the climactic eruptions of several PDCs that formed the Colón ignimbrite. The ignimbrite is over $80 \mathrm{~m}$ thick at its type locality, Colón (Figure 3), and is primarily a massive, poorly welded ignimbrite, with thin and densely welded ignimbrites that occur to the west of the caldera. A sanidine ${ }^{40} \mathrm{Ar}-{ }^{39} \mathrm{Ar}$ age on the Colón ignimbrite yielded $7.3 \pm 0.5 \mathrm{Ma}$. This unit accounts for a minimum DRE volume of 27.5 $\mathrm{km}^{3}$. After Colón ignimbrite, several lava domes were emplaced along a ring fracture that traces the caldera rim. Some of these domes are related to pumice fallouts with a local extent and minor-volume ignimbrites that make a pyroclastic fan deposit next to the dome. Lavas and pyroclastic deposits associated with the domes are nearly aphyric, with less than 0.1 vol. $\%$ of quartz and sanidine. Within the domes is observed flow-banded, pristine, aphyric obsidian, referred here to as Rim Dome Obsidian (RDO). The last caldera event was the emplacement of an intra-caldera lava dome, 4 x 2 $\mathrm{km}$ in size, which was cut by normal faulting along its center, forming a small apical graben with a NE orientation. The dome and the graben formed 


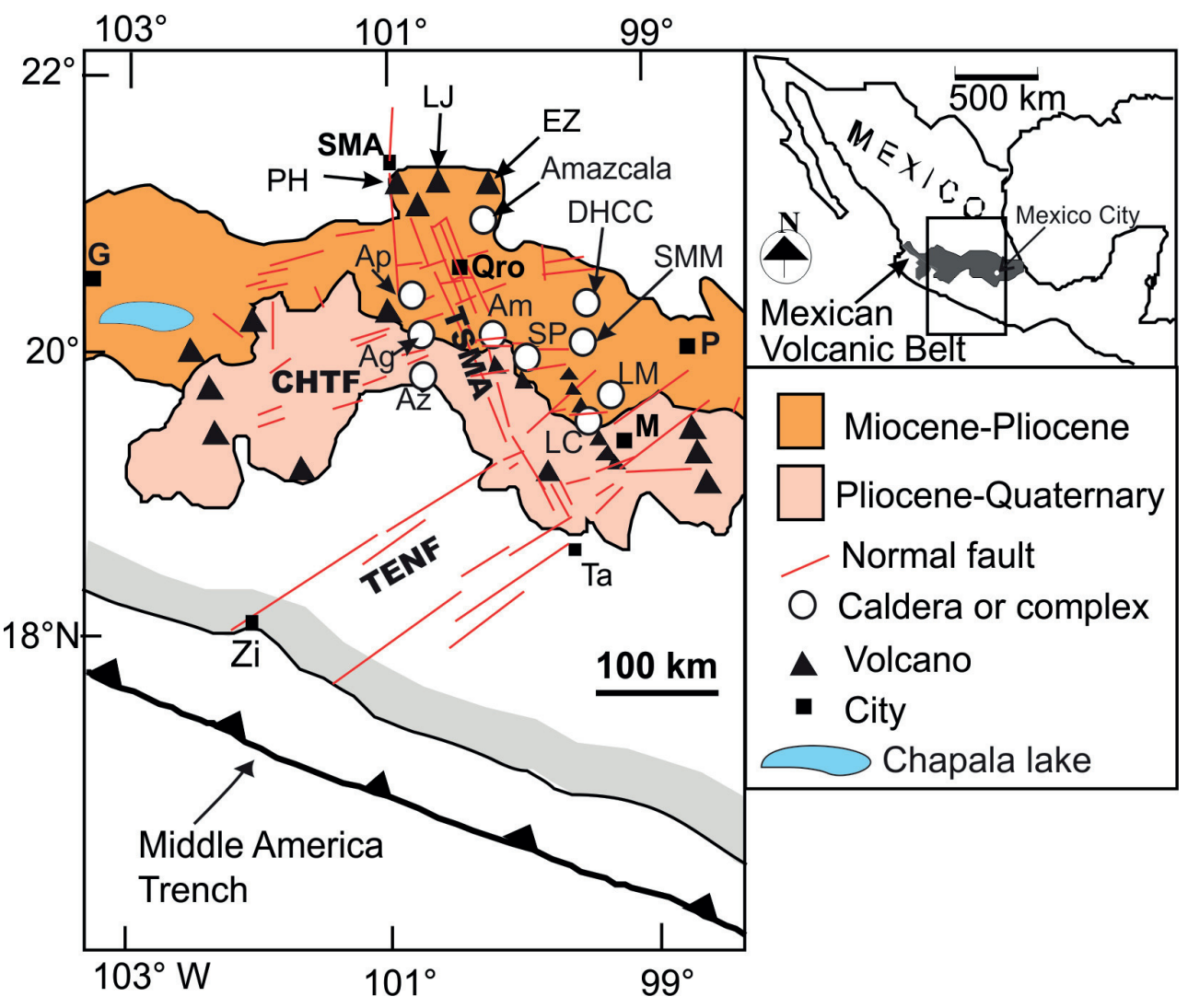

Figure 1 Index map of the Mexican Volcanic Belt province and of the calderas at the central sector of it, including the Amazcala caldera, which is the northernmost caldera of the volcanic province. Calderas: Ag: Agustinos, Ap: Apaseo, Am: Amealco, DHCC: DonguinyóHuichapan caldera complex; SMM: Santa María Macua, SP, San Pedro (Temascalcingo), LM: La Muerta, LC: La Catedral; volcanic complexes: Az: Azufres, volcanoes: PH: Palo Huérfano, LJ: La Joya, EZ: El Zamorano; cities: G: Guadalajara, SMA: San Miguel de Allende, Qro: Querétaro, P: Pachuca, M: Mexico City, Ta: Taxco, Zi: Zihuatanejo, CHTF: Chapala-Tula Fault System; TSMA: Taxco-San Miguel de Allende Fault System; TENF: Tenochtitlán Fault System.

during the resurgence of the caldera, following the model of Smith and Bailey (1968). The dome consists entirely of devitried rhyolite with distinct flow banding, containing chatoyant sanidine (3 vol. \%) and quartz $(3-5$ vol. $\%)$. It yielded a ${ }^{40} \mathrm{Ar}-{ }^{39} \mathrm{Ar}$ age of $6.6 \pm 0.3 \mathrm{Ma}$ on a sanidine separate.

The caldera products overlie middle Miocene andesitic lava flows, andesitic domes, lacustrine deposits, Oligocene (30-31 Ma) ignimbrites, and crystal-rich rhyolitic domes (Figure 3). Caldera products are overlain by lacustrine deposits, and by andesitic and basaltic lavas erupted from nearby modest-sized shield volcanoes $(<400 \mathrm{~m}$ in height $)$ and cinder cones, such as Cenizas (5.2 \pm 0.2 Ma),
Cimatario (5.6 $\pm 0.4 \mathrm{Ma})$, and San José El Alto, which are post-Colón ignimbrite (Figure 3).

\section{Analytical techniques}

Whole rock pumices and lavas were crushed using an alumina ceramic container and a shatter box. Homogenous powders with -200 mesh particle sizes were used during instrumentation. X-Ray Fluorescence (WD-XRF) analyses were performed for major elements and the trace elements $\mathrm{Rb}, \mathrm{Sr}$, $\mathrm{Ba}, \mathrm{Zr}, \mathrm{Nb}, \mathrm{V}, \mathrm{Cr}, \mathrm{Co}, \mathrm{Ni}, \mathrm{Cu}, \mathrm{Zn}$, Th, and $\mathrm{Pb}$, using a SIEMENS SRS3000 sequential X-Ray 


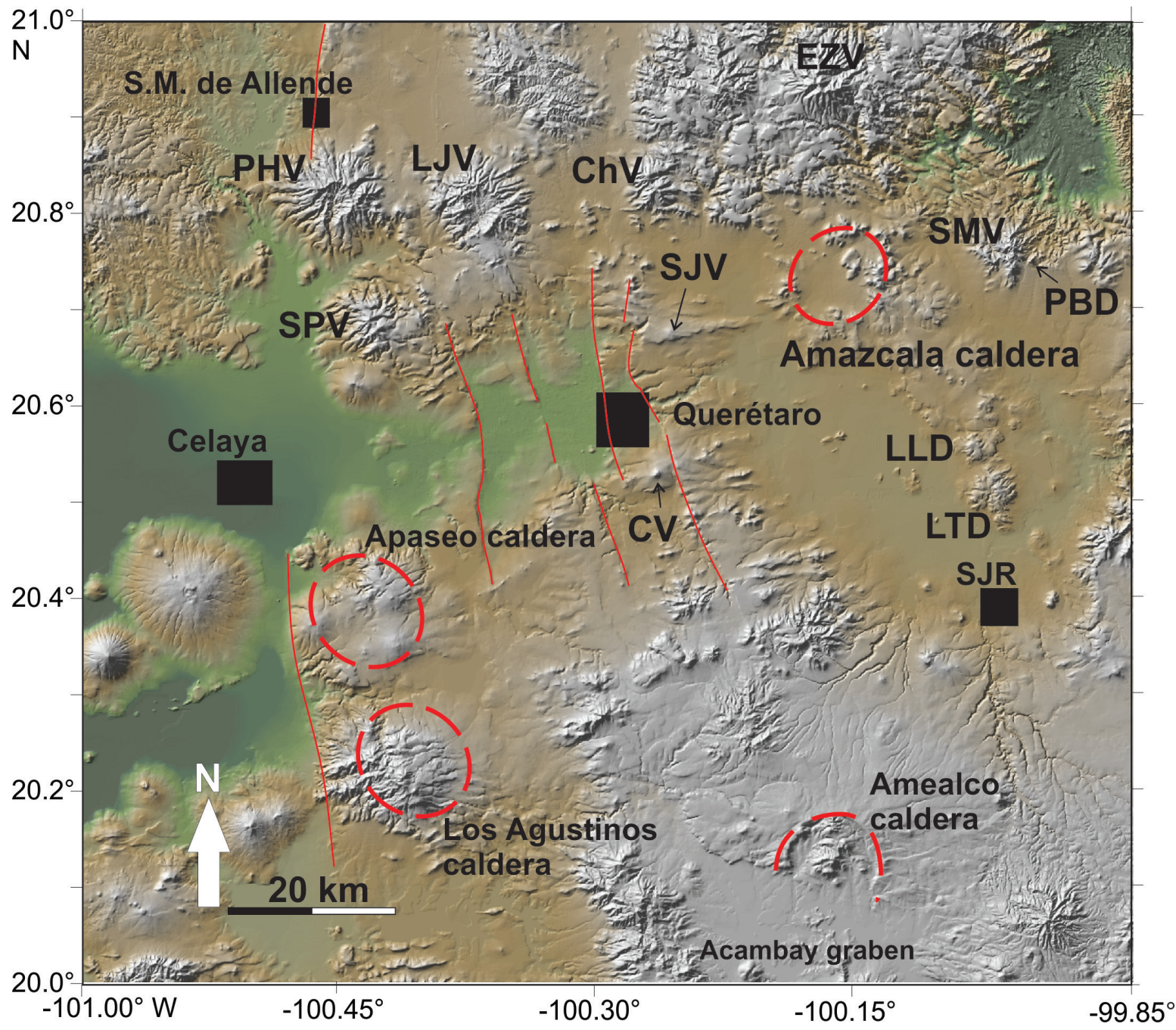

Figure 2 Digital topographic shaded-relief image of the north-central MVB showing the Amazcala caldera outlined by rim lava domes. Other calderas and principal geological features in the region, including main faults, volcanoes and domes are also shown. Volcanoes: EZV-El Zamorano, PHV-Palo Huérfano, LJV-La Joya, SPV-San Pedro, SJV-San José, ChV-Chichimequillas, SMV-San Martin, CV-Cimatario. Domes: PBD: Peña de Bernal, LTD-La Trinidad, LLD-La Laja. Cities (black squares): S.M. de Allende-San Miguel de Allende; SJR:San Juan del Río.

spectrometer at the Geochemical Department of the Institute for Geology of the National Autonomous University of Mexico (UNAM). Details of the technique and data precision are explained in Lozano-Santacruz and Bernal (2005). Major elements were determined in fused beads, prepared with a $\mathrm{Li}_{2} \mathrm{~B}_{4} \mathrm{O}_{7}-\mathrm{LiBO}_{2}$ mix (1:1) using a Fluxy machine designed by Claisse and equipped with Pt-5\% Au crucibles and molds. Trace elements were analyzed using pressed pellets at 30 tons for 30 seconds. Ferrous iron was determined titrimetrically following the procedure of oxidation of ferrous iron to ferric iron in the presence of excess ammonium metavanadate in aqueous solution (Johnson and Maxwell, 1981).

Inductively Coupled Plasma Mass Spectrometry (ICP-MS) was used to determine the lanthanides. Analyses were performed by Ofelia Morton (Ph.D.) at the Institute for Geophysics of UNAM, using a quadru-pole VG-Elemental model PQ3. For the ICP-MS analysis, $0.2 \mathrm{~g}$ of dried powder rock was digested by a strong acid digestion in a microwave furnace. Microwave heating was performed with a commercial CEM sample preparation system. Acid 


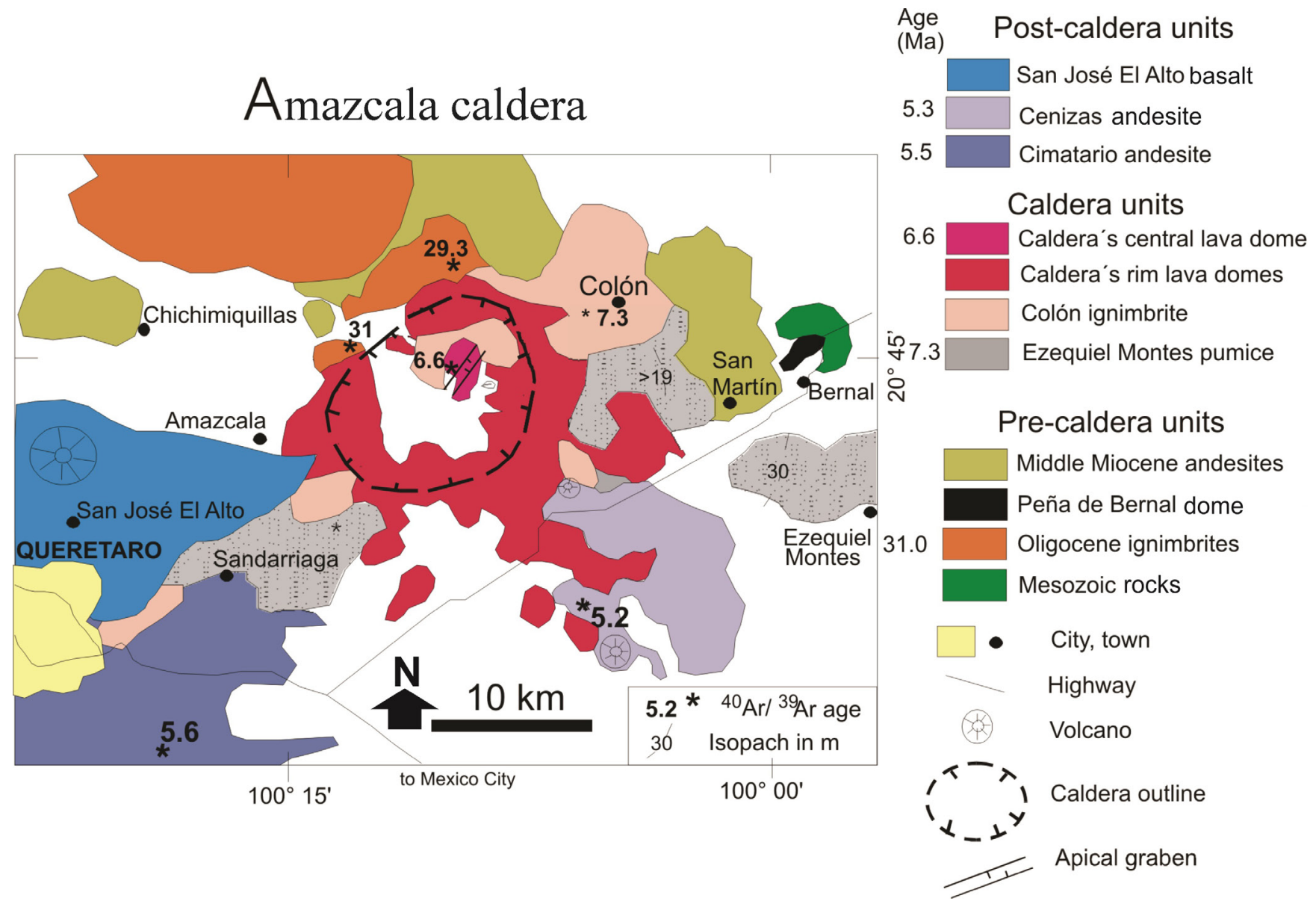

Figure 3 Geologic map of the Amazcala caldera (from Aguirre-Díaz and López-Martínez, 2001).

digestion was carried out in Teflon capsules using a mixture of $\mathrm{HNO}_{3}, \mathrm{HF}$ and HCL at controlled pressure conditions (120 psi). Detection limits are calculated as the concentration equivalent to three times the standard deviation of five replicates of the blank solution. For all elements, it is higher than $50 \mathrm{ppb}$. Calibration was performed with a 1, 10, 100 and $200 \mathrm{ppb}$ multielemental standard solution (SPEX- High Purity) and a blank solution of deionized water, all containing $\mathrm{HNO}_{3}$ at $2 \%$. Matrix effects and instrumental drift can be eliminated by the use of In 115 (10 ppb) as internal standard. The validity of the analytical procedure has been assessed on accuracy and precision tests. These were calculated by comparison of measured and reference values (JA-2). All elements have better precision than $10 \%$ RSD (relative standard deviation). Data obtained for JA-2 showed good agreement with certified values.

\section{Results}

The whole-rock major and trace element data are presented in Table 1. By looking at the volatiles-free data, all caldera products classify as high-silica rhyolites, with $\mathrm{K}_{2} \mathrm{O}$ values varying from $>3$ to $<8$ wt. $\%$ (figures $4 \mathrm{a}$ and $4 \mathrm{~b}$ ). For comparison, basalts of San José El Alto volcano, basaltic andesites of Cenizas and Cimatario volcanoes, and 
Table 1. Whole-rock XRF and ICP-MS analyses. Continued on the next page.

\begin{tabular}{|c|c|c|c|c|c|c|c|c|c|}
\hline Sample & Qro-39 & Qro-4 & Qro-19 & Qro-45 & Qro-65 & Qro-67 & Qro-85 & Qro-86 & Qro-66 \\
\hline Unit & $\begin{array}{c}\text { San José } \\
\text { basalt }\end{array}$ & $\begin{array}{l}\text { Cenizas } \\
\text { andesite }\end{array}$ & $\begin{array}{r}\text { Cima } \\
\text { ande }\end{array}$ & $\begin{array}{l}\text { RDO La } \\
\text { Zorra }\end{array}$ & $\begin{array}{l}\text { RDO Las } \\
\text { Palmas }\end{array}$ & $\begin{array}{l}\text { RDO Las } \\
\text { Palmas }\end{array}$ & $\begin{array}{c}\text { RDO } \\
\text { Ajuchitlán }\end{array}$ & $\begin{array}{c}\text { RDO } \\
\text { Leoncitos }\end{array}$ & $\begin{array}{c}\text { Las Palmas } \\
\text { punice }\end{array}$ \\
\hline 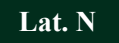 & $0^{\circ} 40.900$ & ' 35 & $20^{\circ} 32.426$ & $20^{\circ} 43$ & $20^{\circ} 42$ & $20^{\circ} 42$ & $20^{\circ}$ & $20^{\circ} 4$ & $20^{\circ}$ \\
\hline Long. W & $0^{\circ} 21.75^{\prime}$ & $100^{\circ} 4.075$ & $100^{\circ} 20.675$ & $100^{\circ} 8.019$ & $100^{\circ} 4.341$ & $100^{\circ} 4.142$ & $100^{\circ} 1.604$ & $100^{\circ} 3.227$ & $100^{\circ} 4.36$ \\
\hline
\end{tabular}

\begin{tabular}{|c|c|c|c|c|c|c|c|c|c|}
\hline $\mathrm{SiO}_{2}$ & 49.53 & 54.92 & 51.75 & 75.46 & 75.57 & 75.80 & 75.85 & 75.36 & 69.83 \\
\hline $\mathrm{TiO}_{2}$ & 1.61 & 2.07 & 1.66 & 0.15 & 0.14 & 0.15 & 0.15 & 0.15 & 0.16 \\
\hline $\mathbf{A l}_{2} \mathbf{O}_{3}$ & 17.41 & 16.85 & 17.22 & 10.90 & 10.99 & 11.02 & 11.02 & 11.06 & 12.03 \\
\hline $\mathrm{Fe}_{2} \mathrm{O}_{3}$ & 5.61 & 4.33 & 2.14 & 1.30 & 1.45 & 1.45 & 1.41 & 1.18 & 2.47 \\
\hline $\mathrm{FeO}$ & 4.17 & 4.43 & 7.43 & 1.69 & 1.43 & 1.43 & 1.43 & 1.69 & 0.91 \\
\hline MnO & 0.17 & 0.14 & 0.15 & 0.04 & 0.04 & 0.05 & 0.05 & 0.05 & 0.04 \\
\hline MgO & 6.74 & 3.71 & 5.77 & 0.00 & 0.00 & 0.00 & 0.00 & 0.00 & 0.76 \\
\hline $\mathrm{CaO}$ & 10.12 & 7.48 & 8.57 & 0.15 & 0.16 & 0.16 & 0.17 & 0.17 & 0.49 \\
\hline $\mathrm{Na}_{2} \mathrm{O}$ & 3.30 & 2.87 & 3.03 & 5.11 & 4.93 & 4.90 & 4.97 & 5.01 & 1.44 \\
\hline $\mathbf{K}_{2} \mathbf{O}$ & 0.45 & 1.23 & 0.91 & 4.36 & 4.43 & 4.55 & 4.50 & 4.52 & 5.42 \\
\hline $\mathbf{P}_{\mathbf{2}} \mathbf{O}_{\mathbf{5}}$ & 0.26 & 0.33 & 0.43 & 0.02 & 0.02 & 0.02 & 0.02 & 0.01 & 0.03 \\
\hline LOI & 0.22 & 0.32 & 0.16 & 0.60 & 0.63 & 0.61 & 0.46 & 0.54 & 5.92 \\
\hline SUM & 99.58 & 98.68 & 99.23 & 99.78 & 99.79 & 100.13 & 100.02 & 99.74 & 99.49 \\
\hline $\mathbf{R b}$ & 12 & 19 & 16 & 233 & 213 & 212 & 213 & 213 & 227 \\
\hline $\mathrm{Sr}$ & 497 & 533 & 560 & 1 & 1 & 1 & 1 & 1 & 1 \\
\hline $\mathbf{B a}$ & 431 & 851 & 559 & 11 & 11 & 11 & 11 & 11 & 11 \\
\hline $\mathbf{Y}$ & 26 & 30 & 47 & 174 & 159 & 160 & 160 & 159 & 225 \\
\hline $\mathbf{Z r}$ & 150 & 189 & 278 & 1819 & 1577 & 1587 & 1579 & 1580 & 1921 \\
\hline $\mathbf{N b}$ & 3 & 12 & 10 & 72 & 63 & 64 & 63 & 64 & 69 \\
\hline $\mathbf{V}$ & 45 & 216 & 184 & 7 & 5 & 5 & 4 & 5 & 5 \\
\hline $\mathrm{Cr}$ & 10 & 53 & 129 & 19 & 14 & 12 & 13 & 14 & 14 \\
\hline Co & 9 & 27 & 36 & 3 & 3 & 3 & 3 & 3 & 3 \\
\hline $\mathbf{N i}$ & 19 & 61 & 27 & 2 & 6 & 1 & 3 & 4 & 4 \\
\hline $\mathrm{Cu}$ & 3 & 23 & 18 & 3 & 3 & 8 & 3 & 3 & 3 \\
\hline $\mathbf{Z n}$ & 68 & 103 & 97 & 325 & 297 & 301 & 297 & 297 & 345 \\
\hline Th & 11 & 6 & 5 & 49 & 45 & 46 & 46 & 45 & 50 \\
\hline $\mathbf{P b}$ & 22 & 8 & 5 & 43 & 39 & 38 & 37 & 40 & 39 \\
\hline $\mathbf{L a}$ & 12 & 19 & 22 & 52 & 49 & 55 & 58 & 53 & 65 \\
\hline $\mathrm{Ce}$ & 33 & 42 & 49 & 143 & 132 & 152 & 161 & 143 & 159 \\
\hline Pr & 5 & 6 & 7 & 19 & 18 & 16 & 22 & 19 & 22 \\
\hline Nd & 22 & 23 & 29 & 84 & 77 & 74 & 84 & 70 & 104 \\
\hline Sm & 6 & 5 & 6 & 21 & 19 & 21 & 25 & 21 & 34 \\
\hline $\mathbf{E u}$ & 2.4 & 1.8 & 2.0 & 0.5 & 0.5 & 0.5 & 0.6 & 0.5 & 1.2 \\
\hline Gd & 6 & 7 & 9 & 24 & 22 & 25 & 28 & 24 & 38 \\
\hline $\mathbf{T b}$ & 1.0 & 0.9 & 0.9 & 4.2 & 3.7 & 4.4 & 5.2 & 4.1 & 7.1 \\
\hline Dy & 7 & 5 & 5 & 28 & 25 & 29 & 33 & 27 & 53 \\
\hline Ho & 1.3 & 1.0 & 1.0 & 5.6 & 4.9 & 5.9 & 7.2 & 5.5 & 10.1 \\
\hline $\mathbf{E r}$ & 4 & 3 & 3 & 17 & 15 & 18 & 21 & 17 & 33 \\
\hline $\mathbf{T m}$ & 0.4 & 0.4 & 0.4 & 2.4 & 2.2 & 2.6 & 3.2 & 2.5 & 4.8 \\
\hline $\mathbf{L u}$ & 0.6 & 0.3 & 0.4 & 2.4 & 2.2 & 2.6 & 3.1 & 2.4 & 5.5 \\
\hline
\end{tabular}


Table 1. (Continuation) Whole-rock XRF and ICP-MS analyses.

\begin{tabular}{|c|c|c|c|c|c|c|c|c|}
\hline Sample & Qro-6a & Qro-36 & Qro-5C & Qro-5D & Qro-12 & Qro-17B & Qro-32 & Qro-38 \\
\hline Unit & $\begin{array}{c}\text { Colón } \\
\text { ignimbrite }\end{array}$ & $\begin{array}{c}\text { Colón } \\
\text { ignimbrite }\end{array}$ & $\begin{array}{l}\text { EMP - up } \\
\text { Ezequiel M }\end{array}$ & $\begin{array}{l}\text { EMP-low } \\
\text { Ezequiel M }\end{array}$ & EMP Griega & $\begin{array}{c}\text { EMP } \\
\text { Balvanera }\end{array}$ & $\begin{array}{c}\text { pre-caldera } \\
\text { andesite N }\end{array}$ & $\begin{array}{l}\text { pre-caldera } \\
\text { andesite E }\end{array}$ \\
\hline Lat. $\mathbf{N}$ & $20^{\circ} 46.617$ & $20^{\circ} 41.14$ & $20^{\circ} 42.015$ & $20^{\circ} 42.015$ & $20^{\circ} 39.812$ & $20^{\circ} 32.351$ & $20^{\circ} 48.200$ & $20^{\circ} 42.21$ \\
\hline Long. W & $100^{\circ} 3.555$ & $100^{\circ} 14.33$ & $99^{\circ} 58.274$ & $99^{\circ} 58.274$ & $100^{\circ} 14.170$ & $100^{\circ} 28.769$ & $100^{\circ} 11.200$ & $100^{\circ} 15.26$ \\
\hline $\mathrm{SiO}_{2}$ & 73.86 & 73.94 & 72.19 & 70.67 & 73.82 & 74.33 & 62.00 & 60.94 \\
\hline $\mathrm{TiO}_{2}$ & 0.14 & 0.14 & 0.14 & 0.16 & 0.13 & 0.14 & 0.97 & 0.95 \\
\hline $\mathbf{A l}_{2} \mathbf{O}_{3}$ & 11.00 & 10.58 & 11.32 & 10.19 & 10.97 & 10.82 & 17.61 & 16.19 \\
\hline $\mathrm{Fe}_{2} \mathrm{O}_{3}$ & 2.40 & 2.29 & 1.82 & 1.77 & 1.73 & 2.58 & 2.60 & 5.58 \\
\hline FeO & 0.78 & 1.04 & 1.30 & 1.17 & 1.17 & 0.39 & 2.48 & 0.39 \\
\hline MnO & 0.03 & 0.05 & 0.03 & 0.03 & 0.03 & 0.03 & 0.09 & 0.10 \\
\hline MgO & 0.32 & 0.00 & 0.33 & 0.05 & 0.13 & 0.08 & 2.54 & 3.33 \\
\hline $\mathrm{CaO}$ & 0.35 & 0.28 & 0.42 & 2.63 & 0.29 & 0.32 & 5.66 & 5.68 \\
\hline $\mathrm{Na}_{2} \mathrm{O}$ & 1.50 & 3.58 & 1.33 & 1.58 & 1.06 & 1.80 & 3.70 & 3.54 \\
\hline $\mathbf{K}_{2} \mathbf{O}$ & 6.26 & 5.37 & 6.67 & 6.59 & 7.51 & 6.86 & 1.71 & 2.52 \\
\hline $\mathbf{P}_{2} \mathbf{O}_{5}$ & 0.01 & 0.01 & 0.01 & 0.01 & 0.03 & 0.05 & 0.28 & 0.28 \\
\hline LOI & 3.73 & 3.36 & 4.65 & 5.84 & 3.69 & 2.95 & 0.58 & 0.52 \\
\hline SUM & 100.38 & 100.64 & 100.21 & 100.68 & 100.56 & 100.35 & 100.22 & 100.02 \\
\hline $\mathbf{R b}$ & 238 & 257 & 214 & 212 & 212 & 208 & 25 & 42 \\
\hline $\mathrm{Sr}$ & 26 & 1 & 21 & 33 & 6 & 9 & 954 & 904 \\
\hline $\mathbf{B a}$ & 44 & 50 & 32 & 31 & 55 & 26 & 520 & 746 \\
\hline $\mathbf{Y}$ & 193 & 177 & 187 & 178 & 181 & 180 & 38 & 26 \\
\hline $\mathbf{Z r}$ & 1335 & 2005 & 1367 & 1248 & 1231 & 1184 & 187 & 224 \\
\hline Nb & 55 & 73 & 55 & 51 & 51 & 50 & 13 & 11 \\
\hline $\mathbf{V}$ & 2 & 5 & 3 & 2 & 3 & 5 & 93 & 108 \\
\hline $\mathrm{Cr}$ & 12 & 17 & 17 & 12 & 10 & 2 & 34 & 64 \\
\hline Co & 6 & 3 & 5 & 4 & 2 & 5 & 13 & 13 \\
\hline $\mathbf{N i}$ & 0.5 & 3 & 4 & 5 & 0.5 & 4 & 11 & 16 \\
\hline $\mathrm{Cu}$ & 10 & 3 & 13 & 6 & 16 & 7 & 19 & 38 \\
\hline $\mathrm{Zn}$ & 307 & 328 & 307 & 282 & 283 & 270 & 70 & 80 \\
\hline Th & 38 & 55 & 43 & 36 & 38 & 28 & 7 & 9 \\
\hline $\mathbf{P b}$ & 41 & 46 & 35 & 34 & 34 & 35 & 14 & 11 \\
\hline La & 70 & 56 & 8 & na & 103 & 106 & 1 & 26 \\
\hline $\mathrm{Ce}$ & 83 & 158 & 19 & na & 181 & 131 & 3 & 62 \\
\hline Pr & 16 & 20 & 3 & na & 23 & 24 & 0 & 9 \\
\hline Nd & 52 & 85 & 9 & na & 75 & 75 & 2 & 36 \\
\hline Sm & 16 & 26 & 3 & na & 22 & 2 & 0.4 & 8 \\
\hline $\mathbf{E u}$ & 0.3 & 0.7 & 0.1 & na & 0.4 & 0.1 & 0.2 & 2.4 \\
\hline Gd & 20 & 30 & 3 & na & 26 & 26 & 0.4 & 6 \\
\hline Tb & 0.6 & 5.6 & 0.9 & na & 5.8 & 5.7 & 0.1 & 1.0 \\
\hline Dy & 23 & 36 & 4 & na & 29 & 28 & 0.3 & 6 \\
\hline Но & 0.8 & 7.8 & 1.0 & na & 5.9 & 5.8 & 0.1 & 1.1 \\
\hline $\mathbf{E r}$ & 14 & 23 & 3 & na & 17 & 17 & 0.2 & 3 \\
\hline $\mathbf{T m}$ & 1.8 & 3.4 & 0.4 & na & 2.2 & 2.1 & 0.1 & 0.5 \\
\hline $\mathbf{L u}$ & 2.0 & 3.3 & 0.5 & na & 2.4 & 2.3 & 0.1 & 0.5 \\
\hline
\end{tabular}


andesites (pre-caldera lava plateaus) of the Amazcala region, are also plotted. From the alumina saturation index plot (Figure 4c), it is observed a trend from peraluminous to peralkaline with time, from the EMP and Colón ignimbrite to the RDO, whereas the peripheral andesites and basalts are metaluminous, as expected for orogenic andesites of the MVB (Gill, 1981; Wilson, 1989). The $\mathrm{K}_{2} \mathrm{O}$ $\mathrm{K}_{2} \mathrm{O} / \mathrm{Na}_{2} \mathrm{O}$ plot shows that the rhyolites of the Amazcala caldera are potassic rhyolites, with the smallest $\mathrm{K}_{2} \mathrm{O} / \mathrm{Na}_{2} \mathrm{O}$ values for the $\mathrm{RDO}$ (Figure 4d). The RDO are comendites, following the classification of Macdonald (1974) and Macdonald et al. (2011) for peralkaline rocks (Figure 4h). However, although the EMP and Colón ignimbrite also fall into the comendite field of Macdonald's (1974) classification, they are not peralkaline, so they cannot be classified as comendites.

Pumices show megascopic evidence for weathering, and in particular, hydration of glass; while the obsidian of RDO is pristine and shiny glass (Figure 5). The raw chemical data suggest that there is something wrong with the vesiculated glasses of Amazcala caldera (pumices), as they are highly enriched in $\mathrm{K}_{2} \mathrm{O}$ and highly depleted in $\mathrm{Na}_{2} \mathrm{O}$ with respect to the comagmatic dense glasses, such as the obsidians of the RDO. Apparently, the pumices of both EMP and Colón ignimbrite were modified by weathering, in this case hydration of glass, whereas the dense glasses (obsidian) were less affected by secondary processes and were able to retain their original chemical characteristics. This secondary hydration problem was corrected as explained below.

\section{1. $\mathrm{Na}_{2} \mathrm{O}$-LOSS AND $\mathrm{K}_{2} \mathrm{O}$-ENRICHMENT IN GLASSES}

It has been shown that silicic glasses can change their original alkali contents by hydration and devitrification (Lipman 1965; Noble 1970; Conrad 1984; White et al., 2003). Noble (1970) describes this problem in particular for comendites. Loss of $\mathrm{Na}$ and the concomitant enrichment of $\mathrm{K}$ is the common observation for hydrated and devitrified glasses. In the Amazcala case, the glasses analyzed are mostly non-devitrified, but pumices are hydrated. The loss of ignition (LOI) values shows that hydration is particularly high in the pumices, and low in the obsidians (Table 1). $\mathrm{Na}_{2} \mathrm{O}$ and $\mathrm{K}_{2} \mathrm{O}$ are the most affected components of Amazcala glasses (Table 1). This is shown in the total alkali-silica (TAS) and in the $\mathrm{SiO}_{2}-\mathrm{K}_{2} \mathrm{O}$ plots (Figures $4 \mathrm{a}$ and $4 \mathrm{~b}$ ). In particular, the $\mathrm{SiO}_{2}-\mathrm{K}_{2} \mathrm{O}$ plot (Figure 4b) shows an unusual enrichment of $\mathrm{K}_{2} \mathrm{O}$ up to almost 8 wt.\%. In contrast, elements apparently not affected by hydration, such as $\mathrm{Al}$ or $\mathrm{Fe}$, change little with respect to $\mathrm{SiO}_{2}$ (Table 1). In order to have useful data for $\mathrm{Na}$ and $\mathrm{K}$ to be used in the classification diagrams, a correction must be applied to the measured values of $\mathrm{Na}_{2} \mathrm{O}$ and $\mathrm{K}_{2} \mathrm{O}$ wt. $\%$.

The effect of total water (assumed here to mostly account for the LOI content) in the $\mathrm{Na}_{2} \mathrm{O}$ and $\mathrm{K}_{2} \mathrm{O}$ is shown in Figure 6, in which two trend lines are plotted for each component. It can be observed that RDO remained practically unchanged with LOI variation; thus, their $\mathrm{Na}_{2} \mathrm{O}$ and $\mathrm{K}_{2} \mathrm{O}$ values were used as the reference "unchanged" values with hydration. The relative difference in percent of the pumice glass with respect to obsidian was used to obtain the correction factor to be applied $(\mathrm{CF} \%)$. The average measured values of $\mathrm{Na}_{2} \mathrm{O}$ and $\mathrm{K}_{2} \mathrm{O}$ wt. $\%$ of the five RDO samples listed in Table 1 were used in this correction. The correction factors to be applied were calculated by means of the equations of the best-fit, squares-regression curves from the plots of $\mathrm{Na}_{2} \mathrm{O}$ and $\mathrm{K}_{2} \mathrm{O}$ measured with their corresponding $\mathrm{CF} \%$ (Figure 7). Table 2 summarizes the correction procedure. All glasses of Amazcala caldera were corrected, including the RDO. However, as shown in Table 2 and as expected, the correction needed for the RDO was practically zero. In contrast, the pumiceous units needed higher correction values (EMP, Palmas pumice, and Colón ignimbrite). Table 3 shows the corrected values and the re-calculation of all the other major elements on the basis of this correction. These new calculated values were normalized volatiles-free and the normalized data were used in all the plots shown next in this work. Figures $4 \mathrm{e}$ 

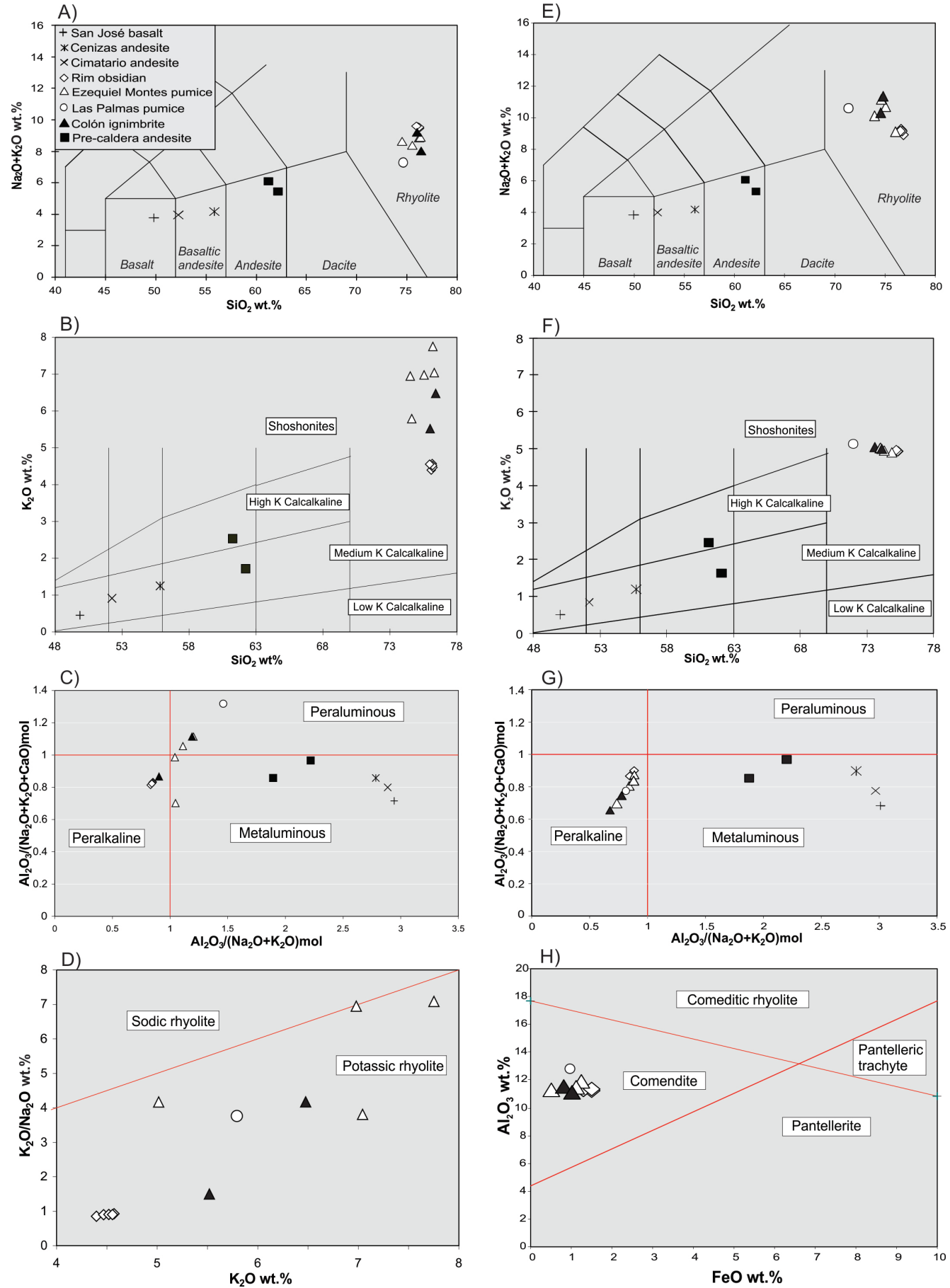

Figure 4 Classification diagrams of the Amazcala caldera and peripheral volcanism. A to D: Uncorrected classification diagrams using Table 1 volatile-free data. $\mathrm{E}$ to $\mathrm{H}$ : Corrected classification diagrams of the Amazcala caldera products using the corrected data of $\mathrm{Na}_{2} \mathrm{O}$ and $\mathrm{K}_{2} \mathrm{O}$ (wt.\%, normalized volatiles-free) from Table 3. A) Uncorrected Total Alkali-Silica plot (TAS -Le Bas et al., 1986). B) Uncorrected $\mathrm{SiO}_{2}-\mathrm{K}_{2} \mathrm{O}$ plot and classification of Peccerillo and Taylor (1976). All caldera products are high-silica rhyolites, rich in $\mathrm{K}_{2} \mathrm{O}$. C) Uncorrected Alumina saturation plot (in mol \%) showing a tendency from peraluminous to peralkaline in the Amazcala caldera rocks, while the peripheral older and younger andesites and basalts are metaluminous. D) Uncorrected $\mathrm{K}_{2} \mathrm{O}-\mathrm{K}_{2} \mathrm{O} / \mathrm{Na}_{2} \mathrm{O}$ plot showing that the Amazcala caldera rhyolites are all potassic. E) Corrected $\mathrm{SiO}_{2}$-Total alkalies (TAS) plot and classification of Le Bas et al. (1986); F) Corrected SiO ${ }_{2}$ $\mathrm{K}_{2} \mathrm{O}$ plot and classification of Peccerillo and Taylor (1976). G) Corrected Alumina saturation plot (in mol \%) showing that all Amazcala caldera rocks are peralkaline, and the peripheral older and younger andesites and basalts are metaluminous. $\mathrm{H}$ ) Corrected FeO-Al $\mathrm{O}_{3}$ wt.\% plot and classification of Macdonald (1974) for peralkaline rhyolites, showing that all caldera products are in the comendite field. 
Table 2. Correction factors to compensate glass hydration for $\mathrm{Na}_{2} \mathrm{O}$ and $\mathrm{K}_{2} \mathrm{O}$ in glasses of Amazcala caldera.

\begin{tabular}{|c|c|c|c|c|c|c|c|c|c|c|c|c|}
\hline Sample & Unit & $\mathrm{Na}_{2} \mathrm{O}$ raw & $\mathrm{K}_{2} \mathrm{O}$ raw & $\begin{array}{c}\text { Average }^{3} \\
\mathrm{Na}_{2} \mathrm{O} \& \\
\mathrm{~K}_{2} \mathrm{O}\end{array}$ & $\begin{array}{c}\text { Difference }^{4} \\
\mathrm{Na}_{2} \mathrm{O}\end{array}$ & $\begin{array}{c}\text { Difference }^{4} \\
\mathrm{~K}_{2} \mathrm{O}\end{array}$ & $\begin{array}{c}\text { Diff \% } \\
\mathrm{Na}_{2} \mathrm{O}\end{array}$ & $\begin{array}{c}\text { Diff \% }{ }^{5} \\
\mathrm{~K}_{2} \mathrm{O}\end{array}$ & $\begin{array}{c}\mathrm{CF}^{6} \\
\mathrm{Na}_{2} \mathrm{O}\end{array}$ & $\begin{array}{l}\mathrm{CF}^{6} \\
\mathrm{~K}_{2} \mathrm{O}\end{array}$ & $\begin{array}{c}\text { Corrected } \\
\mathrm{Na}_{\mathbf{2}} \mathbf{O}\end{array}$ & $\begin{array}{c}\text { Corrected }^{7} \\
\mathrm{~K}_{2} \mathrm{O}\end{array}$ \\
\hline Qro45 & $\mathrm{RDO}^{1}$ of La Zorra dome & 5.11 & 4.36 & 4.98 & -0.13 & 0.62 & -0.0254 & 0.1422 & -0.1536 & 0.1322 & 4.32 & 4.94 \\
\hline Qro65 & RDO of Las Palmas dome & 4.93 & 4.43 & 4.98 & 0.05 & 0.55 & 0.0101 & 0.1242 & -0.0776 & 0.1178 & 4.55 & 4.95 \\
\hline Qro67 & RDO of Las Palmas dome & 4.9 & 4.55 & 4.98 & 0.08 & 0.43 & 0.0163 & 0.0945 & -0.0647 & 0.0937 & 4.58 & 4.98 \\
\hline Qro85 & RDO of Ajuchitlán dome & 4.97 & 4.5 & 4.98 & 0.01 & 0.48 & 0.0020 & 0.1067 & -0.0948 & 0.1037 & 4.50 & 4.97 \\
\hline Qro86 & RDO of Leoncitos dome & 5.01 & 4.52 & 4.98 & -0.03 & 0.46 & -0.0060 & 0.1018 & -0.1117 & 0.0997 & 4.45 & 4.97 \\
\hline QRO5C & EMP $^{2}$ type section & 1.33 & 6.67 & 4.98 & 3.65 & -1.69 & 2.7444 & -0.2534 & 2.6982 & -0.2517 & 4.92 & 4.99 \\
\hline QRO12 & EMP La Griega & 1.06 & 7.51 & 4.98 & 3.92 & -2.53 & 3.6981 & -0.3369 & 3.1789 & -0.3589 & 4.43 & 4.81 \\
\hline QRO17B & EMP Balvanera & 1.8 & 6.86 & 4.98 & 3.18 & -1.88 & 1.7667 & -0.2741 & 2.0571 & -0.2771 & 5.50 & 4.96 \\
\hline Qro 66 & Las Palmas pumice & 1.44 & 5.42 & 4.98 & 3.54 & -0.44 & 2.4583 & -0.0812 & 2.5298 & -0.0643 & 5.08 & 5.07 \\
\hline QRO6a & Colón ignimbrite & 1.5 & 6.26 & 4.98 & 3.48 & -1.28 & 2.3200 & -0.2045 & 2.4433 & -0.1944 & 5.17 & 5.04 \\
\hline Qro 36 & Colón ignimbrite & 3.58 & 5.37 & 4.98 & 1.40 & -0.39 & 0.3911 & -0.0726 & 0.6003 & -0.0560 & 5.73 & 5.07 \\
\hline
\end{tabular}

' RDO: Rim dome obsidian;

${ }^{2}$ EMP: Ezequiel Montes Pumice;

${ }^{3}$ Average of raw values of $\mathrm{Na}_{2} \mathrm{O}$ and $\mathrm{K}_{2} \mathrm{O}$ wt\% of RDO;

${ }^{4}$ Difference between average values of RDO and pumices for $\mathrm{Na}_{2} \mathrm{O}$ and $\mathrm{K}_{2} \mathrm{O}$ in wt.\% ;

${ }^{5}$ Differences shown in percent of wt.\%;

${ }^{6}$ Correction factor applied for all glasses, obtained from best-fit curve (see Figure 8);

${ }^{7}$ Corrected values in wt.\% for all glasses applying the correction factor.

and $4 \mathrm{f}$ show the new TAS classification plot of Le Bas et al. (1986) and the $\mathrm{SiO}_{2}-\mathrm{K}_{2} \mathrm{O}$ classification plot of Peccerillo and Taylor (1976) using the corrected values. The unusual 8 wt. $\%$ values of $\mathrm{K}_{2} \mathrm{O}$ in the uncorrected plot (Figure 4a) changed to the more realistic values of about 5 wt. $\%$ for peralkaline rhyolites in the corrected plot (Figure 4f). By using the corrected values, it is also avoided the use of erroneous classification schemes and other geochemical misinterpretations. For instance, in the alumina-saturation classification, the Amazcala pumices would be peraluminous instead of peralkaline (see below) and therefore, they would not be comendites as defined by Macdonald (1974).

\subsection{GLASSIFICATION AND GHEMICAL GHARACTERISTICS WITH GORREGTED VALUES}

All caldera products are high-silica rhyolites $\mathrm{SiO}_{2}$ $=73-75$ wt. $\%$ ) and $\mathrm{K}_{2} \mathrm{O}$ values around $5 \mathrm{wt.} \%$ (figures $4 \mathrm{e}$ and $4 \mathrm{f}$ ). The alumina saturation index plot using the corrected values (Figure $4 \mathrm{~g}$ ) shows a peralkaline composition for all of the Amazcala caldera rocks, whereas the peripheral andesites and basalts are metaluminous. By using the corrected values, it is now clear that all Amazcala products are comendites, following the classification of Macdonald (1974) and Macdonald et al. (2011) for peralkaline rocks (Figure $4 \mathrm{~h}$ ).

The multi-element plot (Figure 8a), using key trace elements and the element order proposed by Thompson et al. (1983) and Rock (1987), emphasizes the differences between the peralkaline rocks of the Amazcala products with respect to the metaluminous rocks (andesites and basalts) of the area. It is evident the relative enrichment of the LIL elements $\mathrm{Rb}, \mathrm{K}$, Th, of practically all REE, and of the HFSE Nb, Zr, and $\mathrm{Y}$ of the Amazcala caldera units. In contrast $\mathrm{Ba}, \mathrm{Sr}, \mathrm{P}$ and $\mathrm{Ti}$ are depleted in all the caldera products. From this diagram it is also noticeable that the patterns of the andesites and basalts do not show strong depletions or enrichments as the peralkaline rocks do, and andesites and basalts show moderate negative anomalies for $\mathrm{Nb}$, which are more typical characteristics of orogenic andesites (Gill, 1981). In the rare earths elements (REE) chondrite-normalized plot (Figure 8b), it is observed an enrichment of all REE (except Eu) in all the caldera products with respect to the andesites and basalts of the region. A deep Eu negative anomaly and flat patterns characterize the caldera products, whereas the 

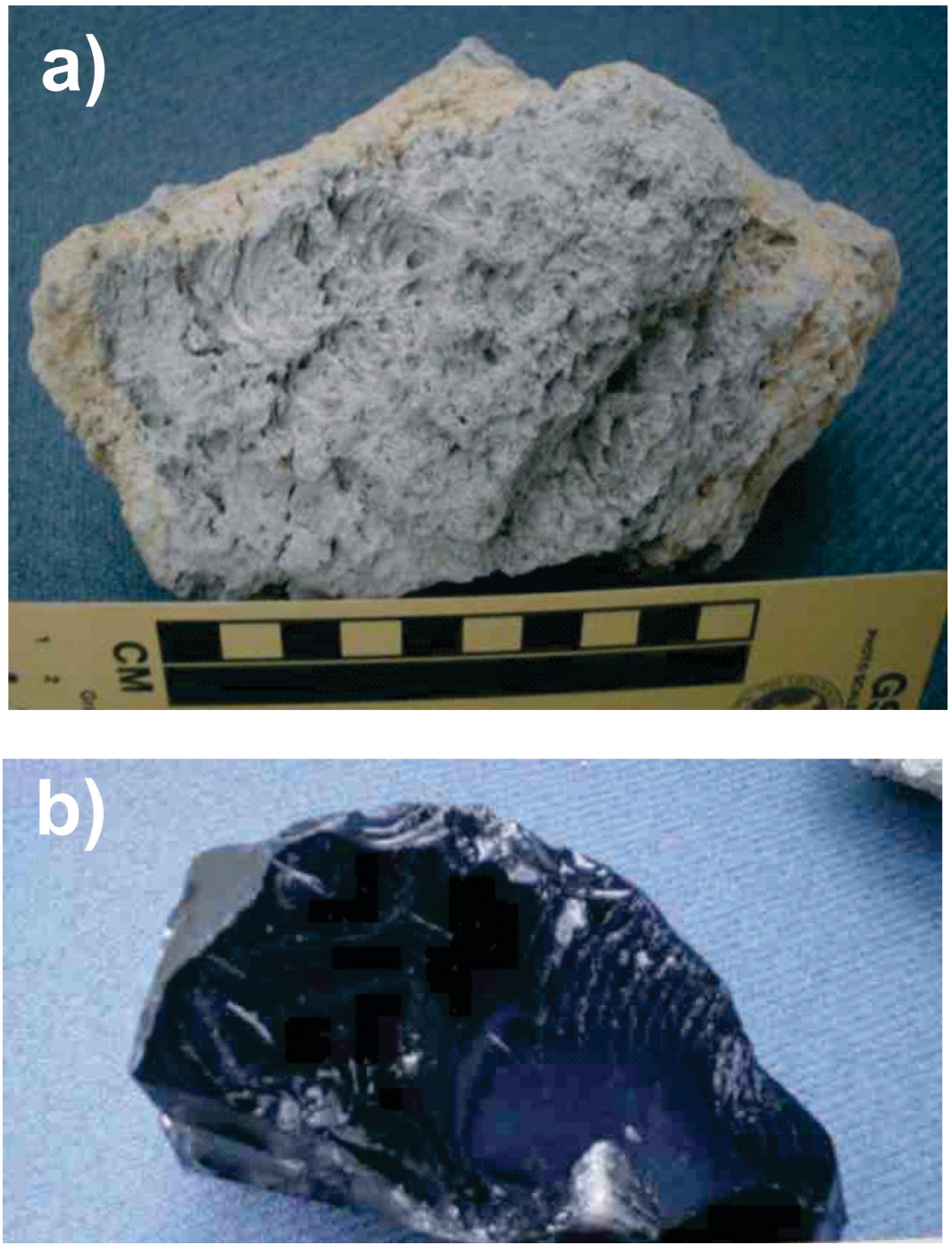

Figure 5 Photographs of Amazcala caldera glasses; a) pumice clast of Ezequiel Montes Pumice (EMP) showing that is relatively more weathered than the RDO; b) obsidian from the Rim Lava Domes (RDO) showing it is a pristine fresh glass.

andesites and basalts show a negative slope, with a little or non-existent Eu negative anomaly, as expected for andesites from volcanic arcs (Wilson, 1989).

The HFSE, in particular, show drastic enrichments with respect to the peripheral andesites and basalts, as shown in four La-HFSE variation diagrams (Figure 9). It is clear a separation into two groups, the HFSE-poor rocks (andesites and basalts), and the HFSE-rich rocks (Amazcala). Amazcala rocks are markedly richer in $\mathrm{Zr}$ (1500 - $2000 \mathrm{ppm}$ ) compared to the peripheral andesites and basalts (100 - $200 \mathrm{ppm})$, and have relatively higher values in $\mathrm{Nb}$ (70 vs. 10 ppm), Y (150 - 200 vs. $20-30 \mathrm{ppm})$, and Th (10 vs. $30-50 \mathrm{ppm})$. The andesite-basalt group cluster tightly in the low end of the diagrams, independently of whether they are pre- or post-caldera.

The enrichment with time of some elements and the depletion in others can be observed by using multi-element histogram plots normalized to a relatively less evolved rock or to an earlier rock in the co-magmatic sequence (Hildreth, 1979). For instance, from EMP to Colón ignimbrite, $\mathrm{Rb}, \mathrm{Th}$, $\mathrm{Nb}, \mathrm{Zr}$, Y slightly increase, with a marked enrichment in Sr, whereas La, Ce, $\mathrm{P}$ and $\mathrm{Tb}$ decrease, and the others remain practically unchanged (Figure 10a). From Colón ignimbrite to RDO these 

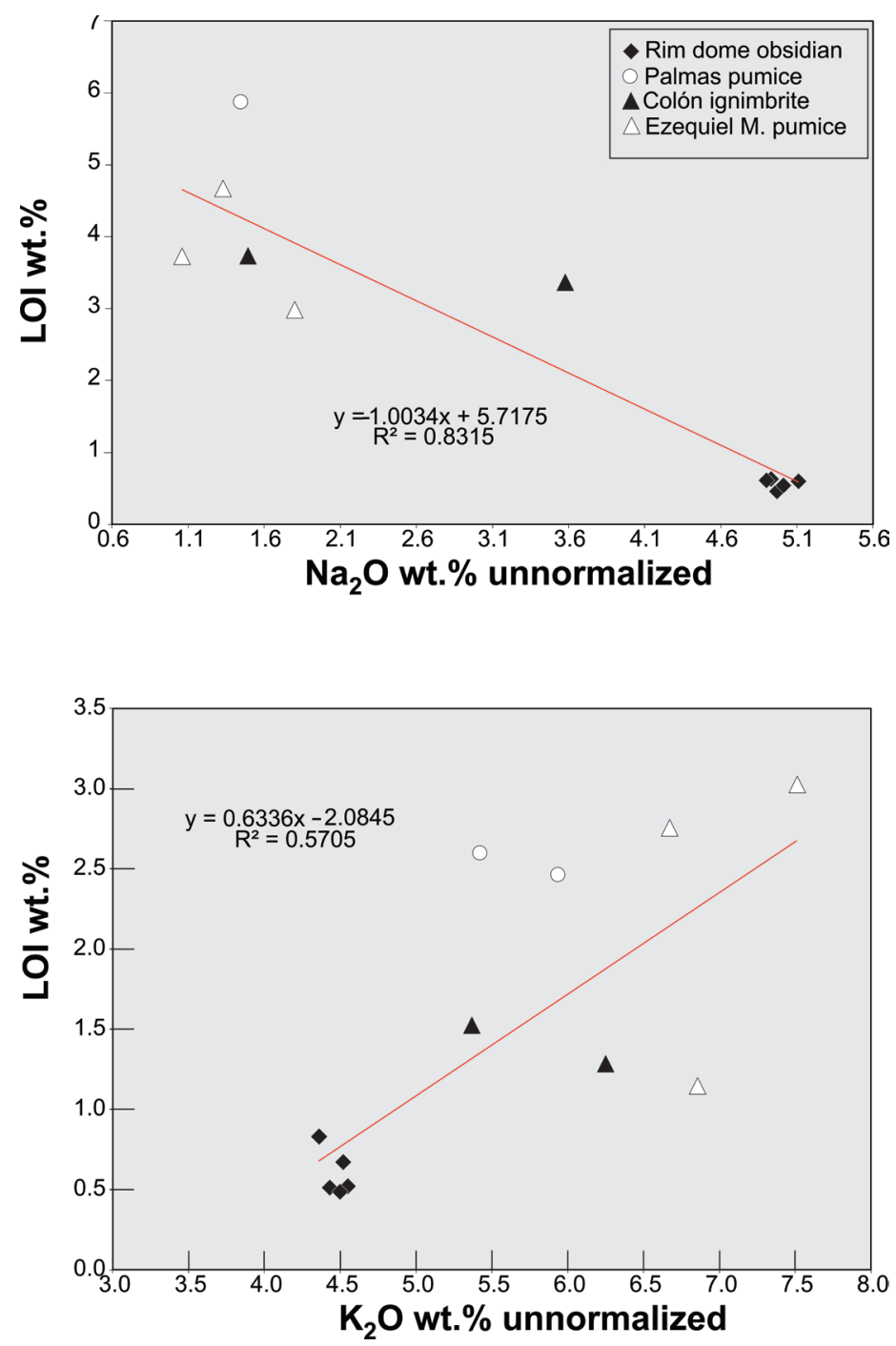

Figure 6 a) $\mathrm{Na}_{2} \mathrm{O}$-LOI and b) $\mathrm{K}_{2} \mathrm{O}$-LOI variation plots of Amazcala caldera glasses, where LOI is the loss of ignition value of the wholerock XRF analysis (Table 1), using unnormalized measured values. The best-fit line and corresponding equation is also shown for each plot.

variations are more notorious, and $\mathrm{Th}, \mathrm{Nb}, \mathrm{Ce}$, $\mathrm{Nd}, \mathrm{P}, \mathrm{Sm}, \mathrm{Zr}$, Tb, and Tm increase, whereas $\mathrm{Ba}$ and Sr substantially decrease, and the rest of the elements practically do not change (Figure 10b), as well as from EMP to RDO (Figure 10c). In general, the RDO are the most representative evolved rocks of the Amazcala caldera and are used in a comparison with the less evolved rocks in the area, including the pre-caldera andesites and the post-caldera andesites and basalts (Figures 10d, $10 \mathrm{e}$ and 10f). All caldera products are enriched in the LILE, HFSE (except Ti) and the REE, and are drastically depleted in $\mathrm{Ba}, \mathrm{Sr}, \mathrm{P}$ and Ti. Some elements are highly enriched, such as $\mathrm{Rb}, \mathrm{K}, \mathrm{Nb}$, Th, Zr and Y, and in lesser extent the REE. These patterns are observed in all three major caldera units, EMP, Colón ignimbrite and RDO.

By looking at the most mafic units that may represent the parental magmas for Amazcala caldera, that is, San José basalt and Cenizas basaltic andesite, it is observed that Cenizas lavas are much more enriched in most key elements than the San José basalt (Figure 11). For instance, $\mathrm{Nb}$ is about 4 times larger in Cenizas. Cenizas basaltic andesite is also enriched in many other key elements, such as Rb, K, La, Ce, Sr, Nd, P, Zr, Ti, and Y (Figure 11), and 

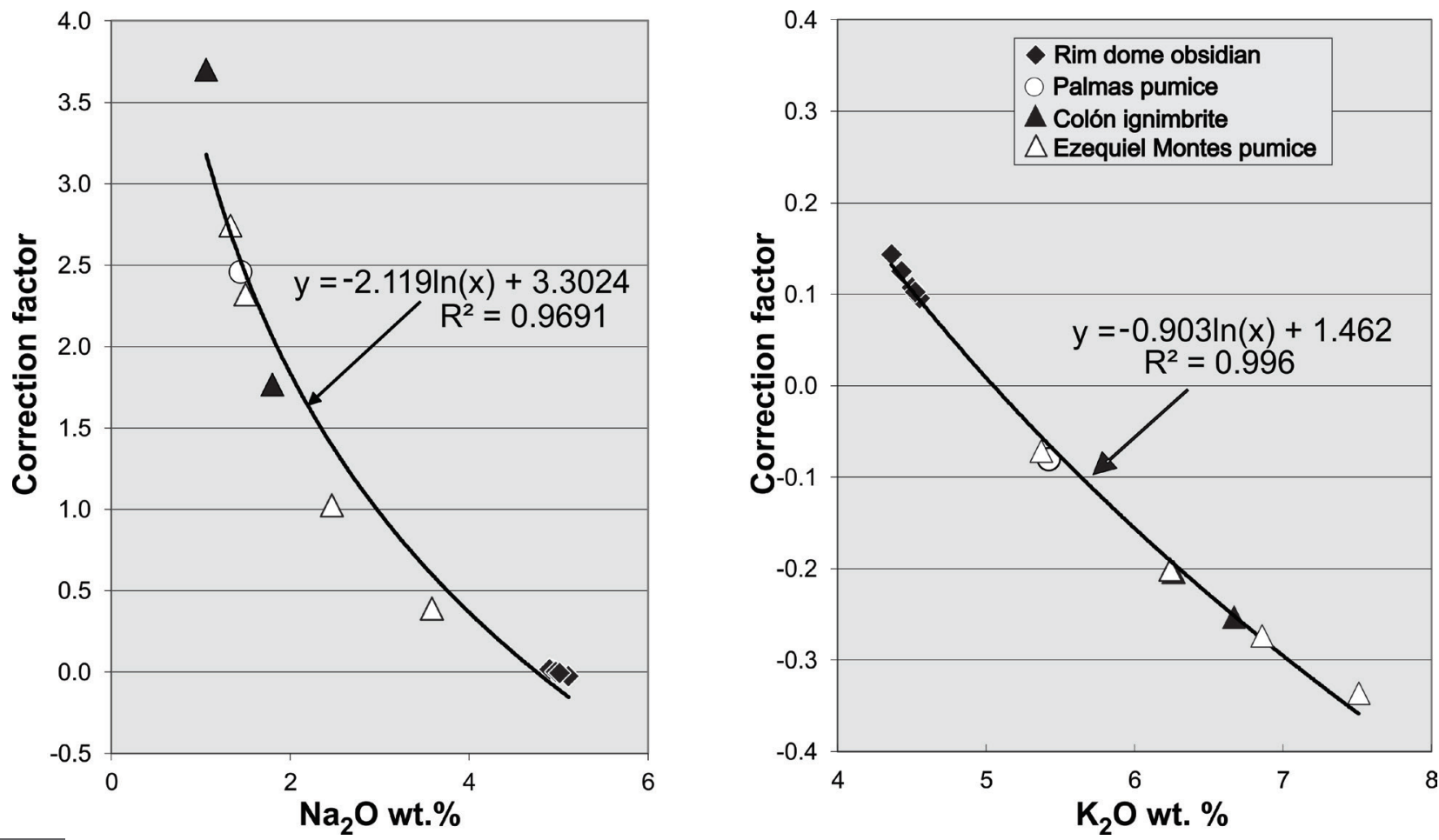

Figure 7 Correction factor (CF) for glass hydration in the Amazcala caldera glasses. a) $\mathrm{Na}_{2} \mathrm{O}-\mathrm{CF}$ and b) $\mathrm{K}_{2} \mathrm{O}-\mathrm{CF}$ plots, where $\mathrm{Na}_{2} \mathrm{O}$ and $\mathrm{K}_{2} \mathrm{O}$ are the measured unnormalized values in wt.\% of Table 1, and the correction factor represents the relative difference in wt.\% of the measured $\mathrm{Na}_{2} \mathrm{O}$ and $\mathrm{K}_{2} \mathrm{O}$ contents between the glasses and the unchanged reference values for $\mathrm{Na}_{2} \mathrm{O}$ and $\mathrm{K}_{2} \mathrm{O}$ (the average of the $\mathrm{Na}_{2} \mathrm{O}$ and $\mathrm{K}_{2} \mathrm{O}$ measured values for the RDO of Table 1). The best-fit curve for each plot and corresponding equations are also indicated. See Table 2 for the calculation procedure.

it is only depleted in Th and $\mathrm{Tb}$, with $\mathrm{Ba}$ and $\mathrm{Sm}$ showing small depletions. Particularly important to notice are the HFSE (Nb, Zr, Ti and Y), and the LILE (except Th), which are relatively abundant in the Cenizas basaltic andesite with respect to San José basalt. Cenizas vent is closer to the Amazcala caldera than the vent of San José basalt (Figure 3). Therefore, it seems that Cenizas basaltic andesites could better represent the parental magmas for the Amazcala caldera products because they are next to the caldera and are already enriched in the HFSE and LILE as the units of Amazcala caldera.

\section{Discussion}

Amazcala is a relatively well-preserved structure, with a clear caldera outline marked by the rim and central lava domes (figures 2 and 3). The erupted pumice and lavas are still glassy at several places, in spite of their age of $7.3-6.6 \mathrm{Ma}$. However, a correction for hydration of glass was necessary for the pumices. The caldera products have chemical characteristics that are not observed in most known silicic calderas of the MVB, which are predominantly calc-alkaline, like Humeros, Huichapan, and Amealco calderas (Ferriz and Mahood, 1984; Milán et al., 1993; Aguirre-Díaz, 1996, 2001a, 2001b; Aguirre-Diaz et al., 1997, 1998; Aguirre-Díaz and López-Martínez, 2009), as expected for a continental margin volcanic arc. However, there are the cases of La Primavera and Las Navajas peralkaline calderas in the western sector of the volcanic province (Mahood, 1981; Nelson and Hegre, 1990) that are mentioned later in this section. All products of the Amazcala caldera are $\mathrm{K}_{2} \mathrm{O}$-rich, high-silica rhyolite. The Amazcala caldera erupted initially $>8.8 \mathrm{~km}^{3}(4.4$ $\mathrm{km}^{3}$ as dense rock equivalent) of peralkaline pumice, and then $>36.7 \mathrm{~km}^{3}\left(27.5 \mathrm{~km}^{3}\right.$ as dense rock 
Table 3. Whole-rock chemical analyses of the Amazcala caldera area using corrected values in Amazcala glasses. Continued on next page.

\begin{tabular}{|c|c|c|c|c|c|c|c|c|c|c|c|c|c|c|}
\hline \multirow{2}{*}{ Sample } & \multirow{2}{*}{ Unit } & $\mathrm{SiO}_{2}$ & $\mathrm{TiO}_{2}$ & $\mathbf{A l}_{2} \mathbf{O}_{3}$ & $\mathrm{Fe}_{2} \mathrm{O}_{3}$ & $\mathrm{FeO}$ & MnO & MgO & $\mathrm{CaO}$ & $\mathrm{Na}_{2} \mathrm{O}$ & $\mathbf{K}_{2} \mathbf{O}$ & $\mathbf{P}_{2} \mathbf{O}_{5}$ & LOI* & SUM \\
\hline & & \multicolumn{13}{|c|}{ Corrected values in wt. $\%$} \\
\hline Qro39 & San José basalt & 49.5 & 1.61 & 17.4 & 5.61 & 4.17 & 0.17 & 6.74 & 10.12 & 3.30 & 0.45 & 0.26 & 0.22 & 99.6 \\
\hline QRO4 & Cenizas andesite & 54.9 & 2.07 & 16.9 & 4.33 & 4.43 & 0.14 & 3.71 & 7.48 & 2.87 & 1.23 & 0.33 & 0.32 & 98.7 \\
\hline QRO19 & Cimatario andesite & 51.8 & 1.66 & 17.2 & 2.14 & 7.43 & 0.15 & 5.77 & 8.57 & 3.03 & 0.91 & 0.43 & -0.16 & 98.9 \\
\hline Qro45 & RDO La Zorra & 75.5 & 0.15 & 10.9 & 1.30 & 1.69 & 0.04 & 0.00 & 0.15 & 5.11 & 4.36 & 0.02 & 0.60 & 99.8 \\
\hline Qro65 & RDO Las Palmas & 75.6 & 0.14 & 11.0 & 1.45 & 1.43 & 0.04 & 0.00 & 0.16 & 4.93 & 4.43 & 0.02 & 0.63 & 99.8 \\
\hline Qro67 & RDO Las Palmas & 75.8 & 0.15 & 11.0 & 1.45 & 1.43 & 0.05 & 0.00 & 0.16 & 4.90 & 4.55 & 0.02 & 0.61 & 100.1 \\
\hline Qro85 & RDO Ajuchitlán & 75.9 & 0.15 & 11.0 & 1.41 & 1.43 & 0.05 & 0.00 & 0.17 & 4.97 & 4.50 & 0.02 & 0.46 & 100.0 \\
\hline Qro86 & RDO Leoncitos & 75.4 & 0.15 & 11.1 & 1.18 & 1.69 & 0.05 & 0.00 & 0.17 & 5.01 & 4.52 & 0.01 & 0.54 & 99.7 \\
\hline QRO5C & EMP type section up & 72.2 & 0.14 & 11.3 & 1.82 & 1.30 & 0.03 & 0.33 & 0.42 & 4.92 & 4.99 & 0.01 & 4.65 & 102.1 \\
\hline QRO5D & $\begin{array}{l}\text { EMP type section } \\
\text { bottom }\end{array}$ & 70.7 & 0.16 & 10.2 & 1.77 & 1.17 & 0.03 & 0.05 & 2.63 & 5.27 & 5.00 & 0.01 & 5.84 & 102.8 \\
\hline QRO12 & EMP La Griega & 73.8 & 0.13 & 11.0 & 1.73 & 1.17 & 0.03 & 0.13 & 0.29 & 4.43 & 4.81 & 0.03 & 3.69 & 101.2 \\
\hline QRO17B & EMP Balvanera & 74.3 & 0.14 & 10.8 & 2.58 & 0.39 & 0.03 & 0.08 & 0.32 & 5.50 & 4.96 & 0.05 & 2.95 & 102.2 \\
\hline Qro 66 & Las Palmas pumice & 69.8 & 0.16 & 12.0 & 2.47 & 0.91 & 0.04 & 0.76 & 0.49 & 5.08 & 5.07 & 0.03 & 5.92 & 102.8 \\
\hline QRO6a & $\begin{array}{l}\text { Colón ignimbrite } \\
\text { pumice }\end{array}$ & 73.9 & 0.14 & 11.0 & 2.40 & 0.78 & 0.03 & 0.32 & 0.35 & 5.17 & 5.04 & 0.01 & 3.73 & 102.8 \\
\hline Qro 36 & $\begin{array}{l}\text { Colón ignimbrite } \\
\text { pumice }\end{array}$ & 73.9 & 0.14 & 10.6 & 2.29 & 1.04 & 0.05 & 0.00 & 0.28 & 5.73 & 5.07 & 0.01 & 3.36 & 102.5 \\
\hline Qro32 & $\begin{array}{c}\text { Pre-caldera andesite } \\
\text { north }\end{array}$ & 62.0 & 0.97 & 17.6 & 2.60 & 2.48 & 0.09 & 2.54 & 5.66 & 3.70 & 1.71 & 0.28 & 0.58 & 100.2 \\
\hline Qro 38 & $\begin{array}{c}\text { Pre-caldera andesite } \\
\text { west }\end{array}$ & 60.9 & 0.95 & 16.2 & 5.58 & 0.39 & 0.10 & 3.33 & 5.68 & 3.54 & 2.52 & 0.28 & 0.52 & 100.0 \\
\hline
\end{tabular}

equivalent) of peralkaline pyroclastic flows (Figure $4 \mathrm{~g})$. It was followed by the emplacement of peralkaline domes that formed the caldera rim rich in obsidian, which were accompanied by more pumice eruptions, which were also peralkaline. These peralkaline rhyolites are comendites in the classification of Macdonald (1974) and Macdonald et al. (2011) of peralkaline rhyolites (Figure 4h), which are rare to occur in a subduction-related volcanic arc and are more typical for intra-plate or continental-rift settings (e.g., Leat et al., 1984; Macdonald et al., 1987, 2011; Wilson, 1989; White et al., 2006; Parker and White, 2008; Macdonald, 2012; Vidal-Solano et al., 2013).

The strong depletions in $\mathrm{Ba}$ and $\mathrm{Sr}$ in the Amazcala products (Figure 8a) suggest a highly efficient crystal fractionation process of feldspar from mafic magmas represented by the San José basalt or Cenizas basaltic andesite. Apatite and Fe-Ti oxides and/or pyroxene fractionation apparently also occurred based on the strong depletions of $\mathrm{P}$ and Ti (Figure 8a). The fact that the Amazcala products are practically aphyric and enriched in $\mathrm{Zr}$, suggests that zircon never crystallized and was preserved dissolved in the melt through all the fractionation process, possibly because the magma was water-saturated (Harrison and Watson, 1983), or because $\mathrm{Na}_{2} \mathrm{O}+\mathrm{K}_{2} \mathrm{O}$ content in the magma was in excess of $7 \mathrm{wt} . \%$ (Carmichael et al., 1974), or a combination of both situations. This is confirmed by the Pearce Element Ratio (PER) diagrams. Following the adaptation of PER diagrams for evolved rocks of Bradshaw (1992) and Figure 12, three main fractional crystallization trends are evident. Assuming an initial magma similar in composition to the most mafic rock in the area (San José basalt), it is inferred that crystal fractionation of magnetite (or Fe-Ti oxides) and clinopyroxene could have formed andesitic magmas similar to the pre-caldera and post-caldera andesites; then, by removal of plagioclase and pyroxene, the earliest rhyolitic magmas of Amazcala caldera represented by EMP were formed; and finally, subsequent removal of feldspar and 
Table 3. (Continuation) Whole-rock chemical analyses of the Amazcala caldera area using corrected values in Amazcala glasses.

\begin{tabular}{|c|c|c|c|c|c|c|c|c|c|c|c|c|c|}
\hline \multirow{2}{*}{ Sample } & \multirow{2}{*}{ Unit } & $\mathrm{SiO}_{2}$ & $\mathrm{TiO}_{2}$ & $\mathbf{A l}_{2} \mathbf{O}_{3}$ & $\mathrm{Fe}_{2} \mathrm{O}_{3}$ & $\mathrm{FeO}$ & MnO & MgO & $\mathrm{CaO}$ & $\mathrm{Na}_{2} \mathrm{O}$ & $\mathbf{K}_{2} \mathbf{O}$ & $\mathbf{P}_{2} \mathbf{O}_{5}$ & SUM \\
\hline & & \multicolumn{12}{|c|}{ Normalized values volatiles-free in wt. $\%$} \\
\hline Qro39 & San José basalt & 49.8 & 1.62 & 17.5 & 5.64 & 4.20 & 0.17 & 6.78 & 10.18 & 3.32 & 0.45 & 0.26 & 100.0 \\
\hline QRO4 & Cenizas andesite & 55.8 & 2.10 & 17.1 & 4.40 & 4.50 & 0.15 & 3.77 & 7.60 & 2.92 & 1.25 & .34 & 00.0 \\
\hline QRO19 & Cimatario andesite & 52.2 & 1.68 & 17.4 & 2.16 & 7.50 & 0.16 & 5.82 & 8.65 & 3.06 & 0.91 & 0.44 & 100.0 \\
\hline Qro45 & RDO La Zorra & 76.1 & 0.15 & 11.0 & 1.31 & 1.70 & 0.04 & 0.00 & 0.15 & 5.15 & 4.40 & 0.02 & 100.0 \\
\hline Qro65 & RDO Las Palmas & 76.2 & 0.14 & 11.1 & 1.46 & 1.44 & 0.04 & 0.00 & 0.16 & 4.97 & 4.47 & 0.02 & 100.0 \\
\hline Qro67 & RDO Las Palmas & 76.2 & 0.15 & 11.1 & 1.46 & 1.44 & 0.05 & 0.00 & 0.16 & 4.92 & 4.57 & 0.02 & 100.0 \\
\hline Qro85 & RDO Ajuchitlán & 76.2 & 0.15 & 11.1 & 1.42 & 1.44 & 0.05 & 0.00 & 0.17 & 4.99 & 4.52 & 0.02 & 100.0 \\
\hline Qro86 & RDO Leoncitos & 76.0 & 0.15 & 11.1 & 1.19 & 1.70 & 0.05 & 0.00 & 0.17 & 5.05 & 4.56 & 0.01 & 100.0 \\
\hline QRO5C & EMP type section up & 74.1 & 0.15 & 11.6 & 1.86 & 1.33 & 0.03 & 0.34 & 0.43 & 5.05 & 5.12 & 0.01 & 100.0 \\
\hline QRO5D & $\begin{array}{l}\text { EMP type section } \\
\text { bottom }\end{array}$ & 72.9 & 0.16 & 10.5 & 1.83 & 1.21 & 0.03 & 0.05 & 2.71 & 5.43 & 5.16 & 0.01 & 100.0 \\
\hline QRO12 & EMP La Griega & 75.7 & 0.13 & 11.2 & 1.77 & 1.20 & 0.03 & 0.13 & 0.30 & 4.54 & 4.94 & 0.03 & 100.0 \\
\hline QRO17B & EMP Balvanera & 74.9 & 0.14 & 10.9 & 2.60 & 0.39 & 0.03 & 0.08 & 0.33 & 5.55 & 5.00 & 0.05 & 100.0 \\
\hline Qro 66 & Las Palmas pumice & 72.1 & 0.17 & 12.4 & 2.55 & 0.94 & 0.04 & 0.78 & 0.51 & 5.25 & 5.24 & 0.03 & 100.0 \\
\hline QRO6a & $\begin{array}{c}\text { Colón ignimbrite } \\
\text { pumice }\end{array}$ & 74.5 & 0.14 & 11.1 & 2.43 & 0.79 & 0.03 & 0.32 & 0.35 & 5.21 & 5.09 & 0.01 & 100.0 \\
\hline Qro 36 & $\begin{array}{l}\text { Colón ignimbrite } \\
\text { pumice }\end{array}$ & 74.6 & 0.14 & 10.7 & 2.31 & 1.05 & 0.05 & 0.00 & 0.28 & 5.78 & 5.11 & 0.01 & 100.0 \\
\hline Qro32 & $\begin{array}{c}\text { Pre-caldera andesite } \\
\text { north }\end{array}$ & 62.2 & 0.97 & 17.7 & 2.61 & 2.49 & 0.09 & 2.55 & 5.68 & 3.71 & 1.72 & 0.28 & 100.0 \\
\hline Qro 38 & $\begin{array}{c}\text { Pre-caldera andesite } \\
\text { west }\end{array}$ & 61.2 & 0.95 & 16.3 & 5.60 & 0.39 & 0.10 & 3.35 & 5.71 & 3.56 & 2.53 & 0.28 & 100.0 \\
\hline
\end{tabular}

Fe-Ti oxides formed the Colón ignimbrite and RDO magmas. By looking only to the caldera products, it is evident that the Ba-, La- Sr-, P-poorest rocks are the RDO and associated Las Palmas pumice (Figure 10), which were compatible elements during fractionation of plagioclase and apatite, indicating extreme removal of plagioclase, K-feldspar, Fe-Ti oxides, and apatite during evolution of the sub-caldera magma chamber. Other peralkaline calderas have shown that crystal fractionation process is an important factor for the final chemistry of the resulting peralkaline rocks, either comendites, trachytes or pantellerites; for instance, the Kenya peralkaline province (e.g., Leat et al., 1984; Macdonald, 2012), Trans-Pecos, Texas (e.g., White et al., 2006; Parker and White, 2008) and the Gardar Province of Greenland (e.g., Macdonald et al., 2014).

\section{Regional tectonic significance}

On the regional tectonic view, the peralkaline nature of the Amazcala caldera suggests an extensional tectonic setting in central Mexico. It is known that comendites are common at intraplate or continental rift settings (e.g., Rytuba and Mckee, 1984; Wilson, 1989; Leat et al., 1984; White et al., 2006; Parker and White, 2008; Macdonald, 2012). In Sonora, Mexico, there are reports of comendites and other peralkaline rocks related with the break-up of Baja California from mainland Mexico (Vidal-Solano et al., 2005, 2008, 2013). In the western sector of the MVB there are reports of comendites in the La Primavera caldera (Mahood, 1980, 1981), of peralkaline ignimbrites near Guadalajara (Figure 1, Mahood et al., 1985), and pantellerites in the Las Navajas summit caldera at 


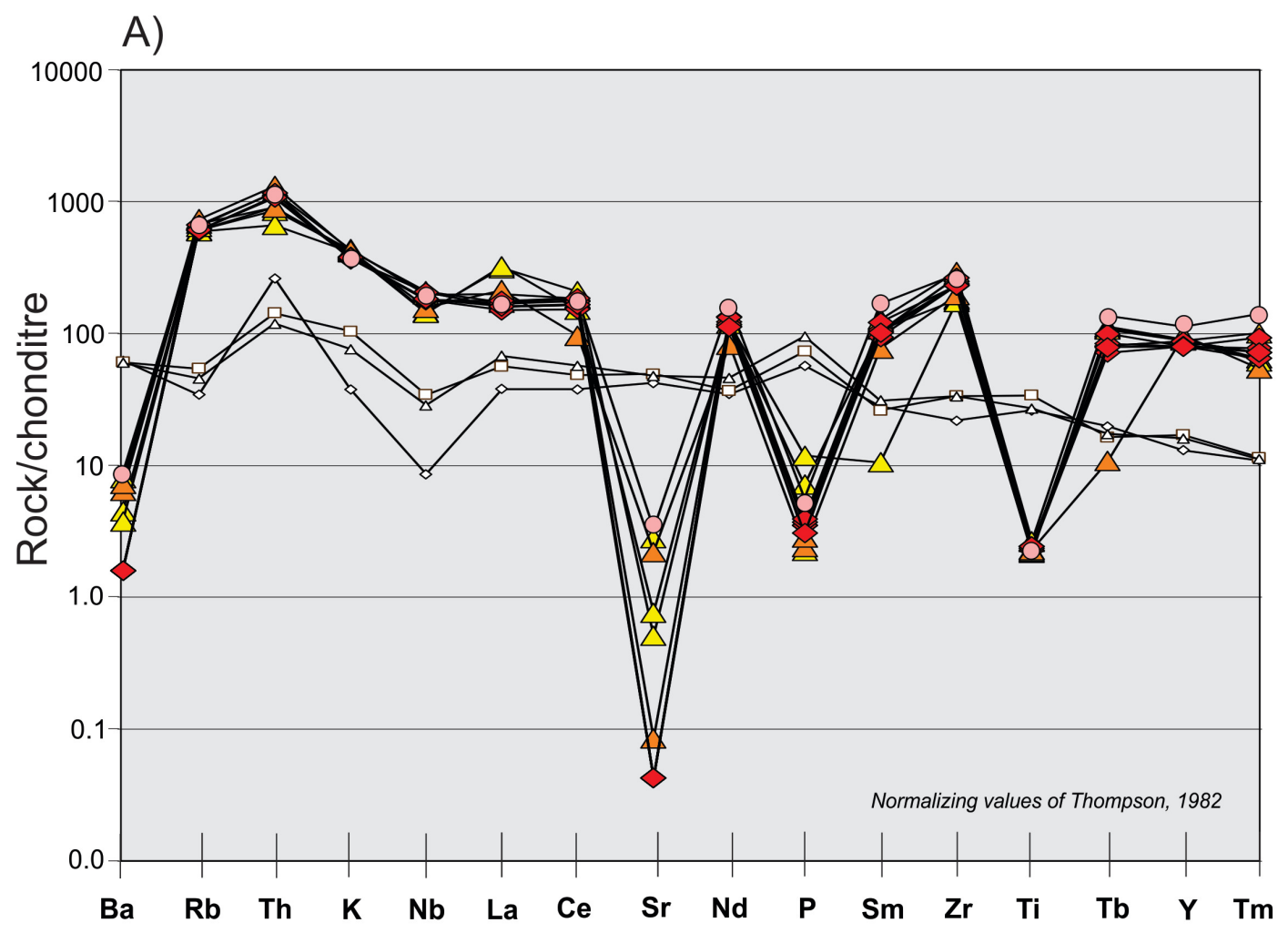

B)

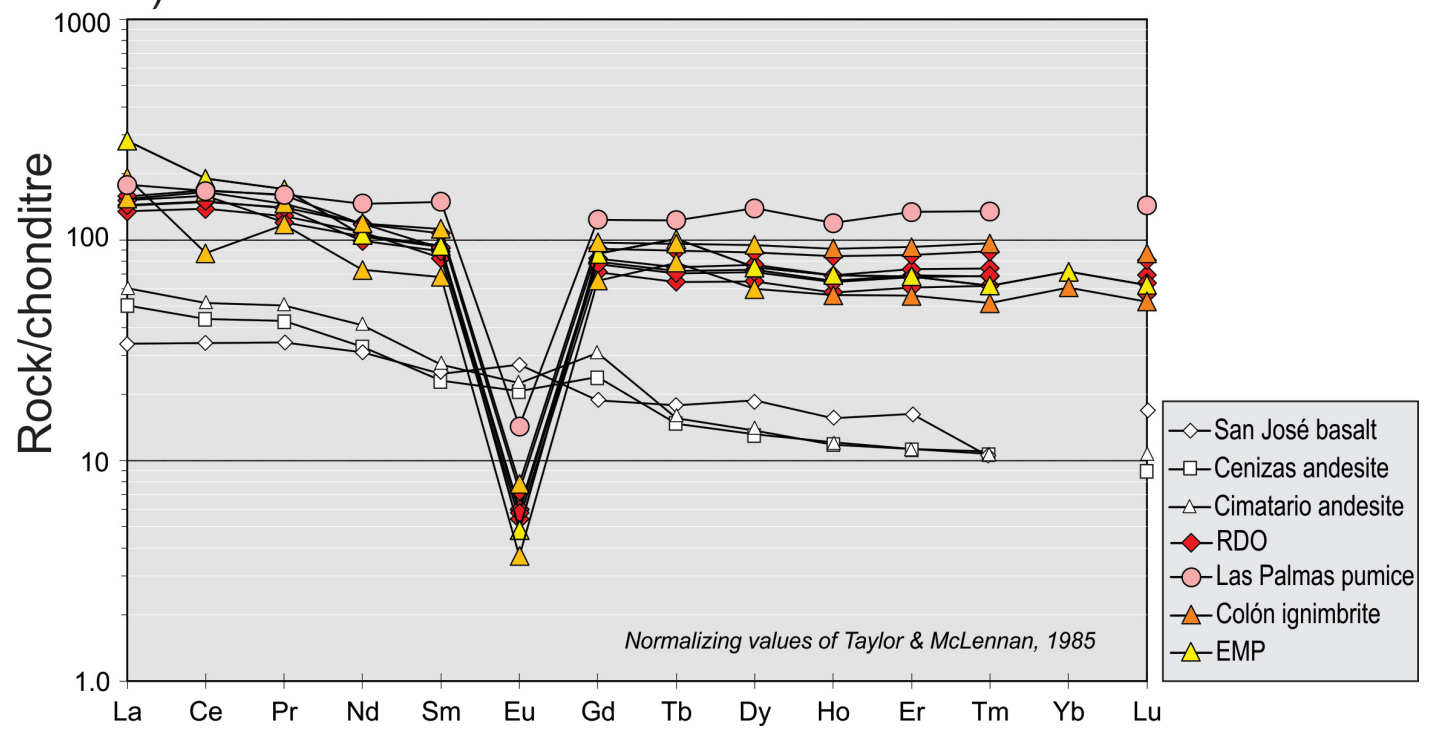

Figure 8 Chondrite-normalized plots of the Amazcala caldera rocks showing contrasting enrichment or depletion of key elements in the Amazcala caldera rhyolites relative to the peripheral andesites and basalts. a) Multielement plot using the element order recommended by Rock (1987) and the normalizing values of Thompson et al. (1982), showing the enrichment in $\mathrm{Rb}, \mathrm{Th}, \mathrm{Nb}, \mathrm{Zr}$, and $\mathrm{Y}$, and in all the REE, except Eu in the caldera units, and strong depletions in Ba, Sr, P, and Ti. b) REE plot showing a flat pattern with a deep Eu-anomaly for the Amazcala caldera rocks, more typical for intraplate evolved volcanism, whereas the andesites and basalts show a negative slope and a small Eu anomaly more common for orogenic andesites (normalizing values of Taylor and McLennan, 1985). 

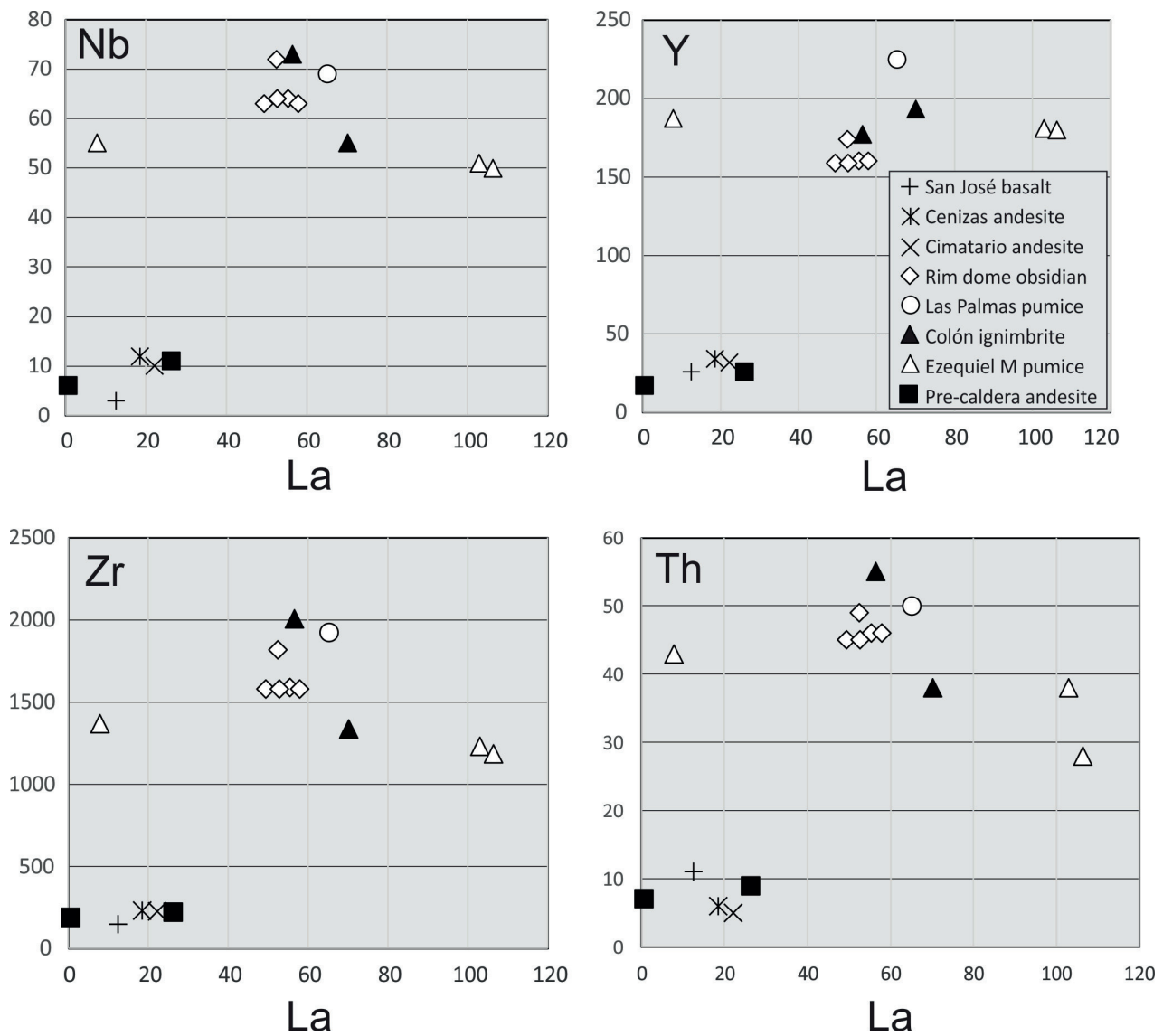

Figure 9 Element-element variation plots showing La vs. the HFSE. The Amazcala comendites are highly enriched in Th, Nb, Zr and $\mathrm{Y}$ with respect to the peripheral andesites and basalts. Zr in particular reaches up to $2000 \mathrm{ppm}$ in Amazcala rocks. Note that the peripheral andesites and basalts are relatively poor in the HFSE and cluster in the lower ends of each plot.

Nayarit State (Nelson and Hegre, 1990). Mahood et al. (1985) and Nelson and Hegre (1990) infer that the peralkaline nature of the western MVB peralkaline rhyolites was related with an extensional regime that was interpreted as a rift-rift-rift tectonic setting by several authors (Luhr et al., 1985; Allan et al., 1991; Garduño and Tibaldi, 1991; Moore et al., 1994; Luhr, 1997). La Primavera caldera was formed near the triple junction, and Las Navajas caldera within the NW-oriented Tepic-Zacoalco rift, where alkalic mafic volcanism is well documented (Nelson and Carmichael, 1984; Nelson and Livieres, 1986; Moore et al., 1994). However, Righter and Rosas-Elguera (2001), among other authors, disagree with the continental-rift explanation for the alkaline mafic lavas of the western $\mathrm{MVB}$, and prefer to explain these mafic rocks as the product of metasomatized mantle within a subduction zone setting. High-silica alkalic rocks, such as peralkaline rhyolites may have evolved through more complex magmatic processes linked with particular tectonic environments. Comendites of the La Primavera caldera are here compared with those of Amazcala by means of a multielement diagram (Figure 13a). The comendites of Amazcala are even more enriched in the LILE and HFSE and more depleted in Ba, $\mathrm{Sr}, \mathrm{P}$, and $\mathrm{Ti}$ than comendites of La Primavera, indicating a richer LILE-HFSE source for the comendites of Amazcala and extremer crystal fractionation. In contrast, the rhyolitic lavas of Amealco caldera, which is at the central sector of the MVB (Aguirre-Díaz, 1996), show typical values for calc-alkaline rhyolites with an orogen- 

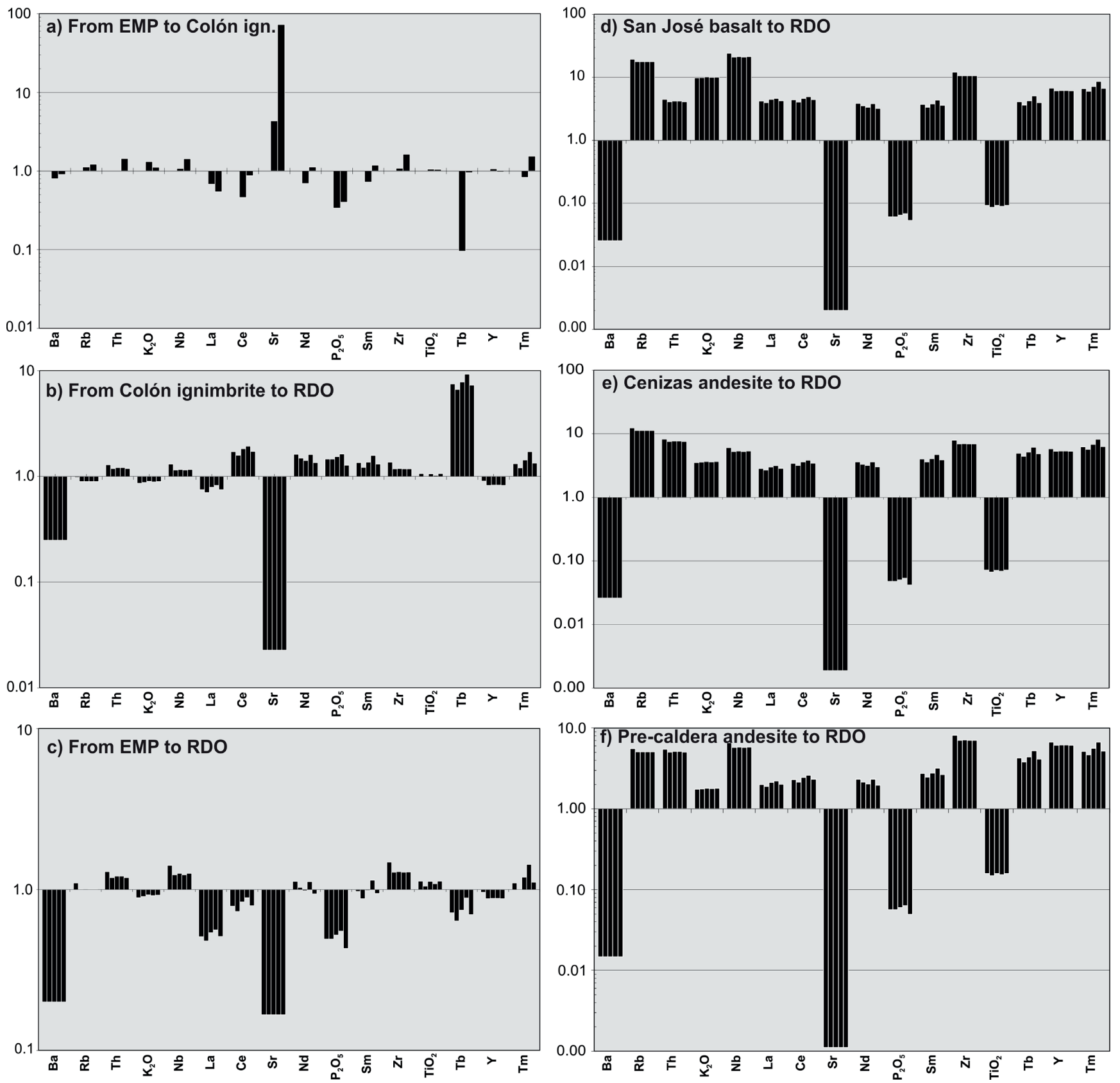

Figure 10 Enrichment and depletion histogram plots of the Amazcala caldera comendites. a) Chemical variation from the first-erupted product, Ezequiel Montes Pumice (EMP-sample Qro12), to the next product, Colón ignimbrite (sample Qro6a). b) Chemical variation from the Colón ignimbrite (Qro6a) to the successive rim dome obsidian (samples Qro65, Qro67, and Qro85). c) Total variation from the EMP (first erupted product) to the RDO (last erupted product). d) Variation between the most primitive rocks nearby Amazcala caldera, the San José basalt to the RDO. e) Variation of RDO with respect to the Cenizas basaltic andesite. f) Variation from the pre-caldera andesites to the RDO. 


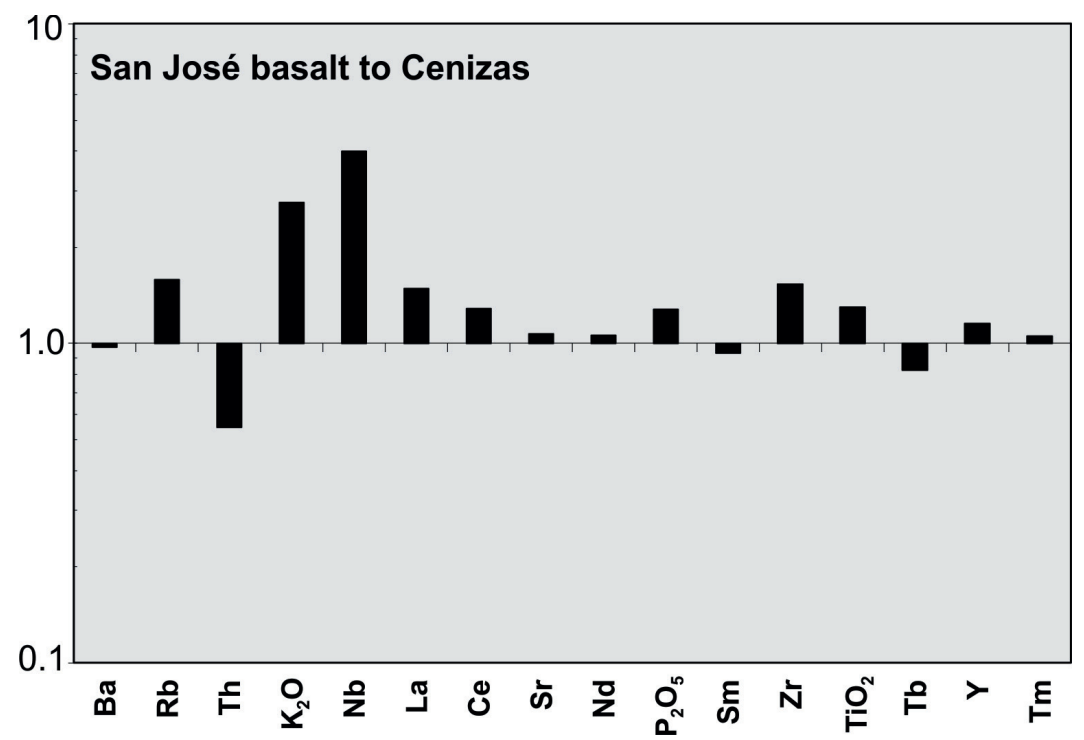

Figure 11 Enrichment-depletion histogram plot of the post-caldera mafic rocks, Cenizas basaltic andesite with respect to San José basalt. Note that Cenizas unit is enriched in LILE and HFSE with respect to San José basalt, and thus, Cenizas may better represent the parental magma for the Amazcala comendites.

ic-like signature. Rhyolites of Amealco are poorer in the LILE and HFSE and do not show the strong depletions in $\mathrm{Ba}, \mathrm{Sr}, \mathrm{P}$ and $\mathrm{Ti}$ as the comendites of Amazcala. Particularly, rhyolites of Amealco show the typical $\mathrm{Nb}$ depletion for orogenic-type rocks (e.g., Wilson, 1989), which is not observed in the Amazcala rocks. In a more global view, it is also compared comendites of Amazcala with those of the Menengai caldera (Figure 13b), which is clearly within a continental rift setting, the Kenya rift (Leat et al., 1984; Macdonald et al., 1987, 201 1; Macdonald, 2012). The comendites at Amazcala have a similar pattern than that of the comendites of Menengai, suggesting that similar petrogenetic processes occurred in both cases, and that the magmas were derived from a source enriched in HFSE, LILE and REE.

Therefore, the comendites of the Amazcala caldera have the signature of magmas generated at a continental rift, but the Amazcala caldera activity is bracketed between subduction-related, calc-alkaline volcanism, represented by the pre-caldera andesites and the post-caldera San José basalt and Cenizas basaltic andesite. There are pre-caldera andesites and dacites that span a long time of calcalkalic-metaluminous activity in the Amazcala caldera region, from at least 12 to $7.5 \mathrm{Ma}$, represented by large andesitic-dacitic stratovolcanoes, such as Palo Huérfano, La Joya, El Zamorano, Chichimequillas, and San Martín (Figure 2; Pérez-Venzor et al., 1996; Valdez-Moreno et al., 1998; Aguirre-Díaz and López-Martínez, 2001; Verma and Carrasco-Núñez, 2003; Aguirre-Díaz et al., 2005; Aguirre-Díaz, 2008), and by widespread andesitic and basaltic-andesitic plateaus erupted from shield volcanoes (Cerca et al., 2000; Aguirre-Díaz et al., 2005; Aguirre-Díaz, 2008). Post-caldera andesites and basalts are represented by the units of Cimatario and Cenizas with an age range of 5.6 to $5.2 \mathrm{Ma}$, and by undated, but stratigraphically younger than Colón ignimbrite, San José basalt (Aguirre-Díaz and López-Martínez, 2001). In this group, it can be also included widespread plateau andesites dated at 6.2 Ma (Valdez-Moreno et al., 1998; Aguirre-Díaz, 2008) that crop out to the north-northwest of Querétaro City (Figure 2).

There is no clear morphological evidence for a continental rift in the Amazcala region, as happens in the Tepic-Zacoalco rift in the western MVB or the rift-rift-rift junction of Guadalajara, or the Gulf of Baja California rift at NW Mexico. 


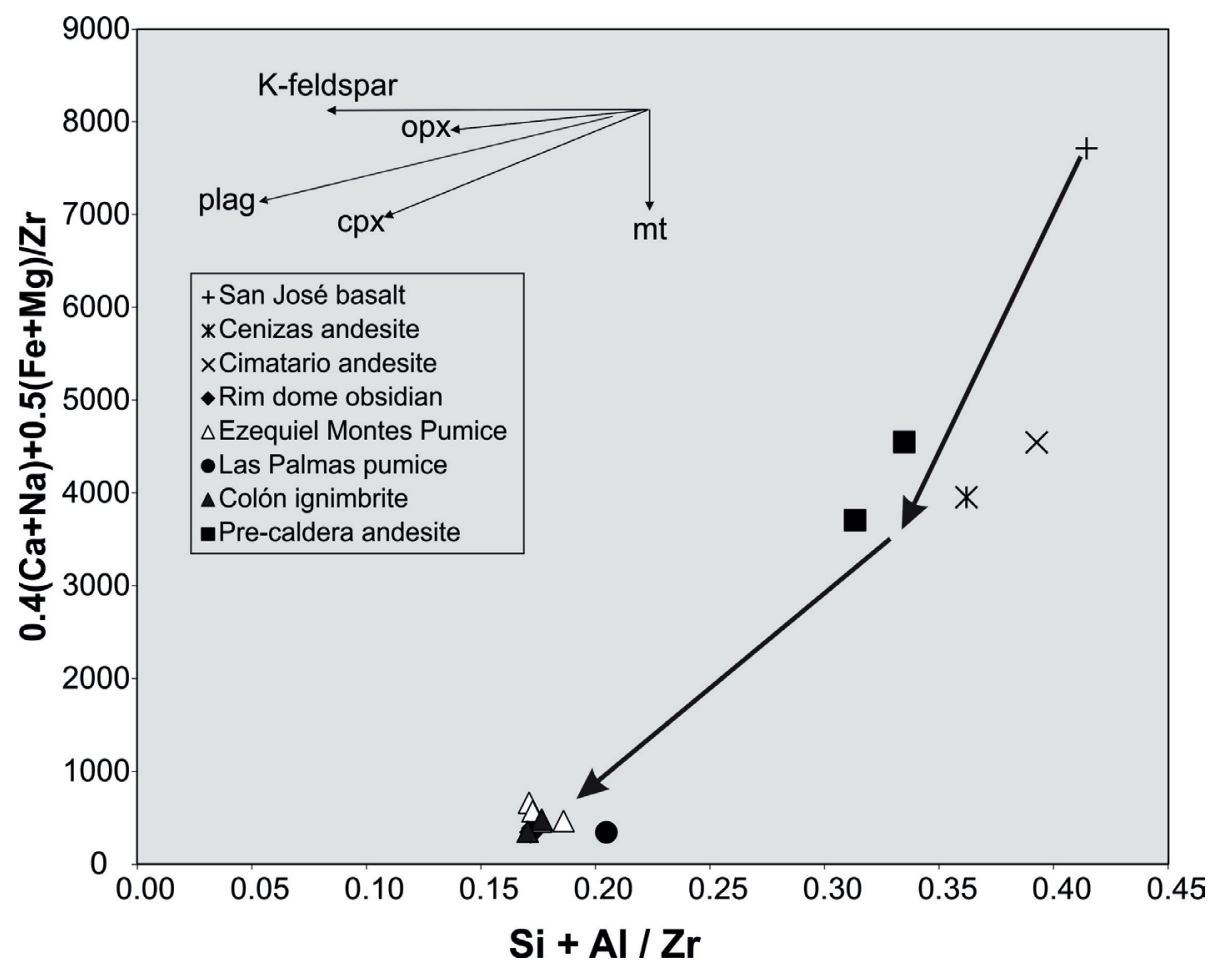

Figure 12 Pearce element ratio diagram for evolved rocks (after Bradshaw, 1992), designed to note the trends caused by crystal fractionation of K-feldspar, orthopyroxene (opx), plagioclase (plag), clinopyroxene (cpx) and Fe-oxides (mt). Rhyolites of the Amazcala caldera may have been originated by crystal fractionation of plagioclase, clinopyroxene and Fe-oxides from andesites represented by the pre-caldera andesites, which in turn could have been the differentiates of a most primitive magma, such as the San José basalt.

The structural studies in the central MVB show two large normal fault systems in the central MVB (Figure 1), the ENE Chapala-Tula fault system (Johnson and Harrison, 1990), and the NNW Taxco-San Miguel de Allende fault system (Demant, 1978; Aguirre-Díaz et al., 2005). These two systems intersect in the Querétaro City-Amazcala caldera zone and form a complex mosaic of grabens and horsts in the area (Figure 14; Aguirre-Díaz et al., 2000, 2005). Regional NNW and ENE faults continue to the East of the Amazcala caldera to the Aljibes graben and Valle del Mezquital in the State of Hidalgo (Suter et al., 1995a, 2001). These faults extend also to the south of Amazcala to the Acambay graben and Perales Fault in the State of Mexico (Suter et al., 1995b, 2001; Landrige et al., 2013; Ortuño et al., 2015; Lacan et al., 2018). It is not clear yet if these extensional features, particularly those in the vicinity of Querétaro City, could be related with the peralkaline pulse of Amazcala caldera. There are other silicic domes of about the same age as those of the Amazcala caldera and relatively close to this center clearly aligned with the regional normal fault systems of the region, suggesting that their emplacement was fault-controlled (Figure 14). There is structural evidence suggesting that extension was episodically active in this region (Suter et al., 1995a, 1995b, 2001; Pérez-Venzor et al., 1996; Aguirre-Díaz et al., 2000; Nieto-Obregón et al., 2000; Aguirre-Díaz et al., 2005), and some of these episodes may have been related to volcanic pulses, either silicic or mafic. It is common to observe thick (over $200 \mathrm{~m}$ ) sequences of lacustrine deposits interbedded with andesite lavas and silicic ash and lapilli fall deposits in the Amazcala area and its surroundings (Kowallis et al., 1998; Aguirre-Díaz and Carranza-Castañeda, 2000a; Cerca et al., 2000; Aguirre-Díaz et al., 2005; Carreón-Freyre et al., 2016). Many of these paleo-lakes were formed by subsidence caused by 


\section{a) Amazcala vs. Amealco and La Primavera}

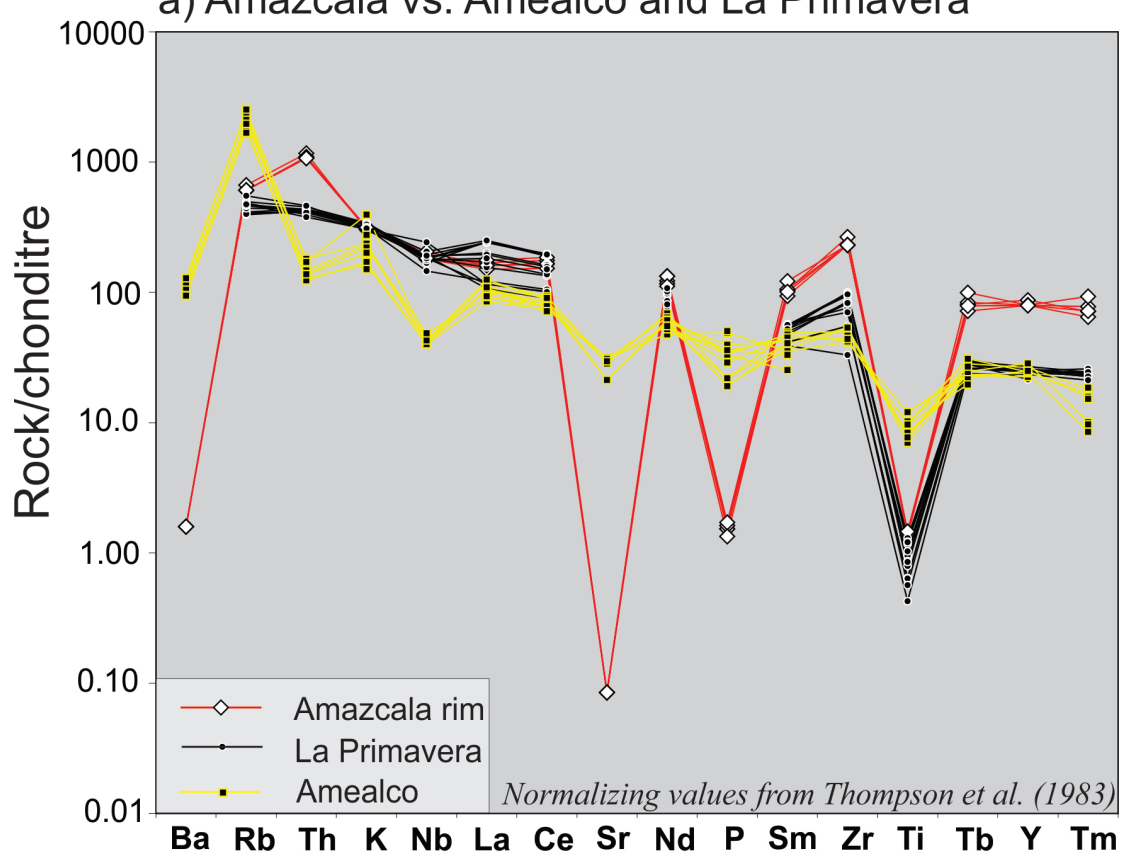

b) Amazcala vs. Menengai (Kenya Rift)

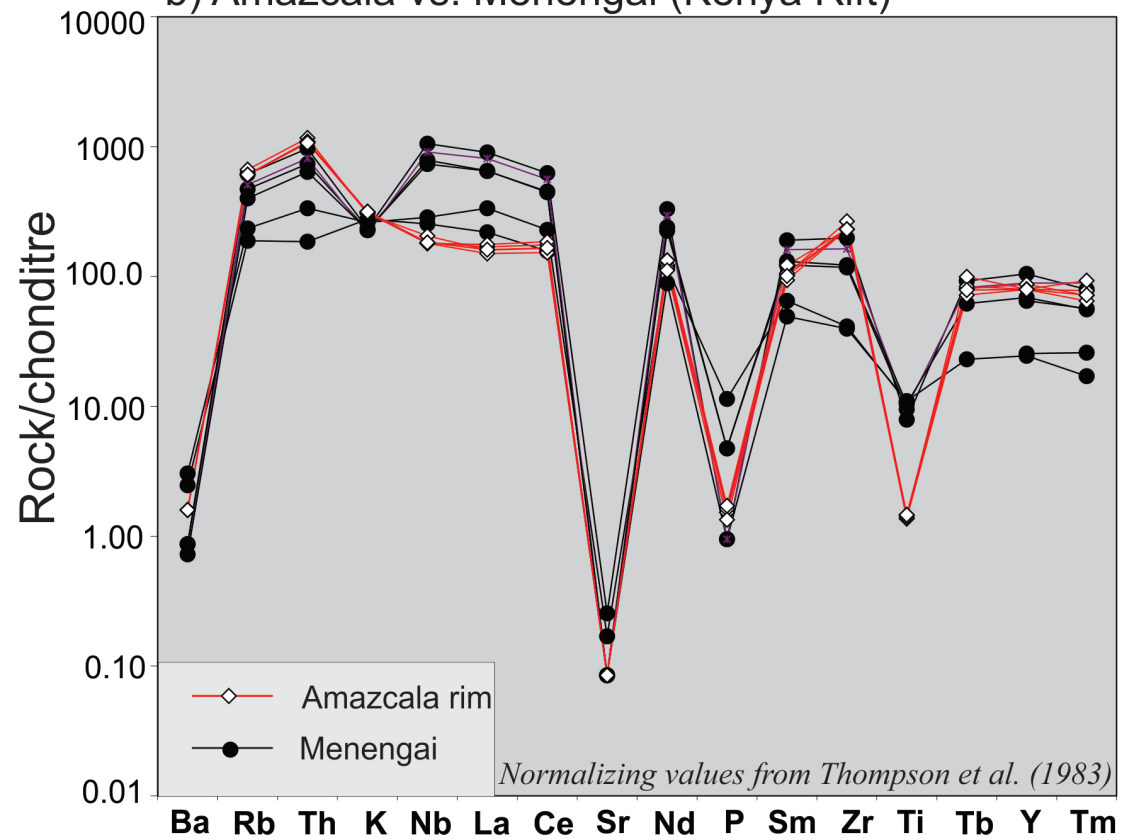

Figure 13 Chondrite-normalized multielement diagrams of the Amazcala caldera compared with rhyolites of other calderas. For Amazcala caldera it was used the RDO as most representative. a) Comparison with calc-alkaline rhyolites of Amealco caldera (AguirreDíaz, 1996, 2001b) and comendites of La Primavera caldera (Mahood, 1980, 1981). b) Comparison with comendites of a typical continental-rift setting, the Menengai caldera at the Kenya rift (Leat et al., 1984). Note that both cases show very similar patterns, with some differences in $\mathrm{Zr}, \mathrm{Y}$ and the HREE at the end of the diagram, where Amazcala is even richer in these than Menengai. 


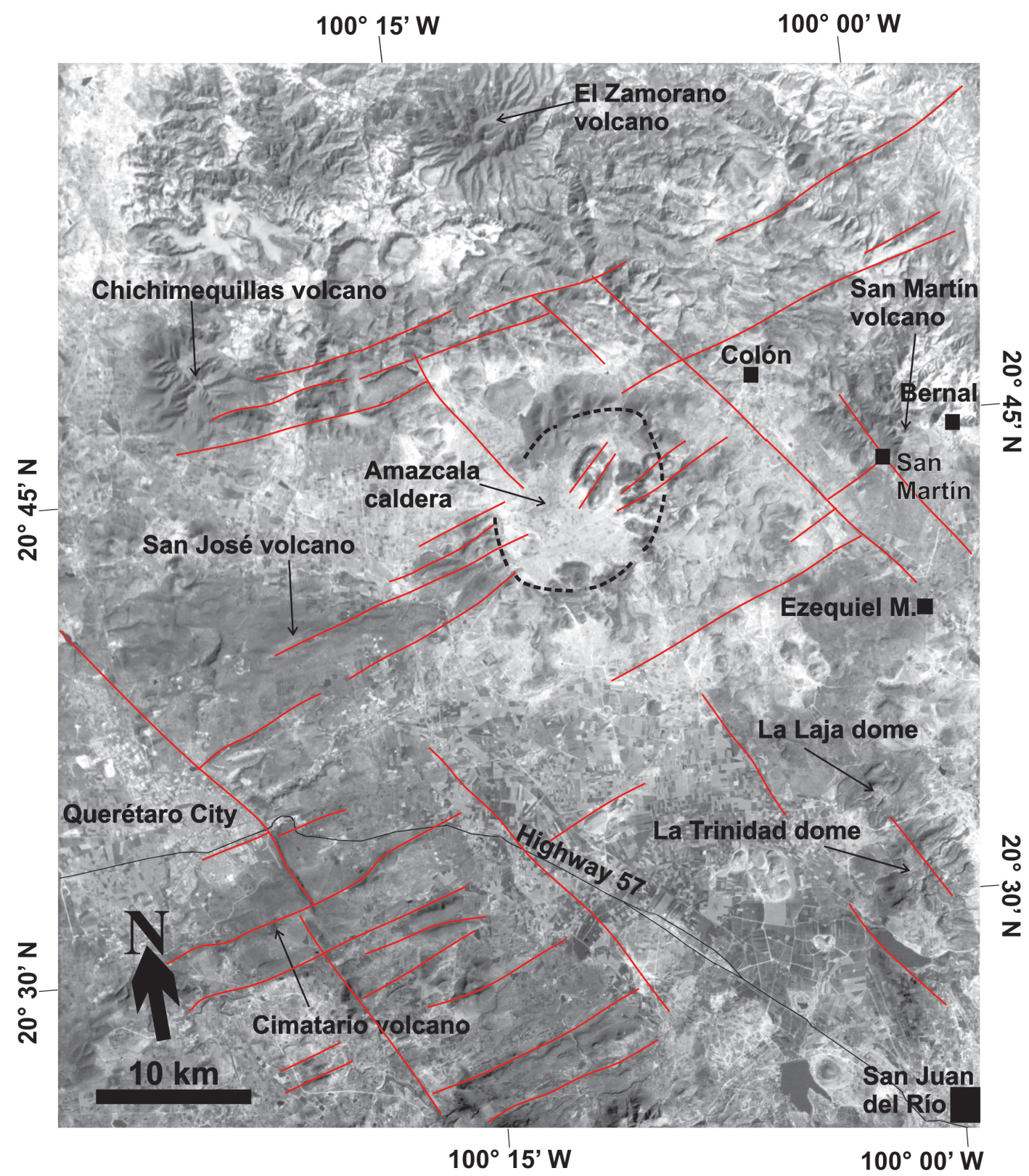

Figure 14 Thematic Mapper Landsat image of the Amazcala-Querétaro region showing the Amazcala caldera outlined by the rim lava domes as well as the NNW and ENE fault systems (red lines) and volcanoes and domes mentioned in text.

normal faulting, such as the Querétaro graben (Aguirre-Díaz et al., 2005; Aguirre-Díaz, 2008; Carreón-Freyre et al., 2016) or the Celaya depression (Cerca et al., 2000). The interbedding of lake deposits with volcanic rocks that span an age of at least 12 to $3 \mathrm{Ma}$ (Aguirre-Díaz and Carranza-Castañeda, 2000a, 2000b; Aguirre-Díaz et al., 2005) indicate that faulting, subsidence, and lake formation occurred repeatedly concurrently with the development of the central MVB, but most of this volcanism is calcalkalic andesites and basaltic andesites.

Alternatively, Amazcala is the farthest inland caldera from the Middle America trench (Figure 1), with a trench-caldera distance of about 480 $\mathrm{km}$ (Aguirre-Díaz, 2001b). This large distance may result in magmas richer in alkaline elements, as have been proposed for continental margin 


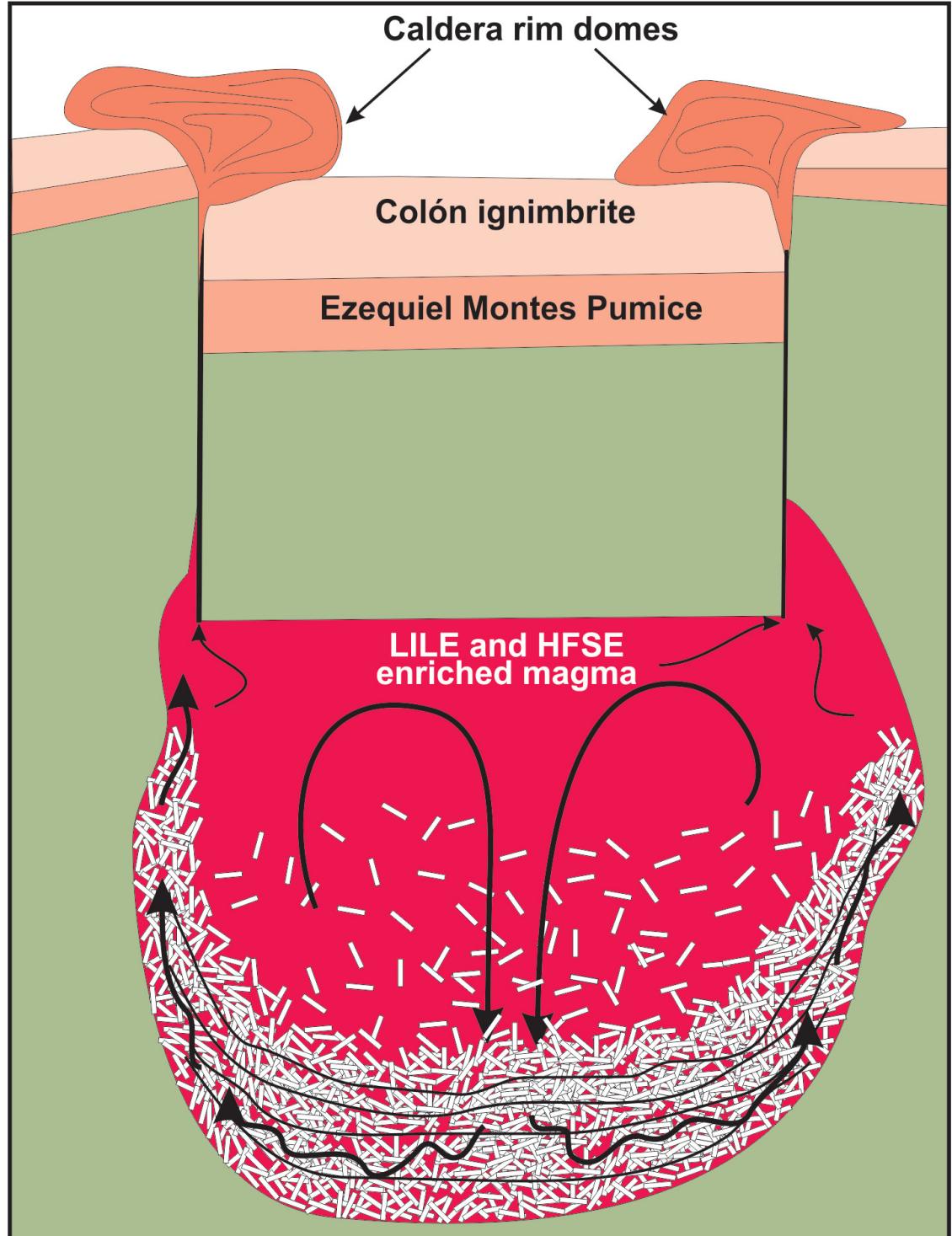

Figure 15 Conceptual model of the subcaldera magma chamber of the Amazcala caldera. It is inferred a previous input, or inputs, of magma from fertile mantle (enriched in HFSE, REE and LILE) reached to shallow levels in the crust. During this ascend and within the last stages at the subcaldera magma chamber, the magma evolved by extreme crystal fractionation of feldspar, apatite, and Fe-Ti oxides (and perhaps clinopyroxene), leaving a final product with little crystal contents, almost $100 \%$ melt. This magma erupted first and formed the EMP unit during Plinian fall eruptions (pre-caldera collapse), then as massive pumiceous pyroclastic density currents that originated the Colón ignimbrite (syn-collapse), and finally mostly as effusive lavas along the ring fracture that formed the obsidian-rich lava domes (RDO) of the caldera rim (post-collapse).

volcanic belts (Coney and Reynolds, 1977). The explanation for this enrichment is that as farther from the trench, the magmas generate at deeper zones of the subducted slab, and these magmas must cross a thicker continental crust, and/or stagnate in the bottom of the crust and develop a MASH (melting, assimilation, storage, and homogenization) process (Hildreth and Moorbath,
1988). This favors a larger crustal contamination, particularly of the most mobile elements, such as $\mathrm{K}, \mathrm{Na}, \mathrm{Rb}, \mathrm{Th}$, and other alkaline elements. Mid-Tertiary alkaline rhyolites of Eastern Chihuahua and Trans-Pecos Texas are an example of this idea (Barker, 1979; McDowell and Clabaugh, 1979; Cameron and Cameron, 1985). Perhaps this was the case in Amazcala caldera, and this would 
explain why it is bracketed between orogenic type andesites and basalts, and why there are no alkaline basalts in the area.

The problem is to explain why only the rhyolites of Amazcala have a peralkaline nature, and why this nature is highly enriched in the HFSE, such as $\mathrm{Nb}, \mathrm{Zr}$, and $\mathrm{Y}$. Nb, in particular, generally becomes more depleted if partial melting involves the continental crust (Gill, 1981; Wilson, 1989). Figure 15 shows a conceptual model of the extreme crystal fractionation process within the subcaldera magma chamber of Amazcala that removed practically all crystals of the caldera products, leaving aphyric magmas, and explaining the drastic depletions in $\mathrm{Ba}, \mathrm{Sr}, \mathrm{P}$, and in lesser extent Ti. Crystal fractionation combined with crustal contamination would produce rhyolites enriched in LILE but poor in HFSE. HFSE-rich evolved magmas must be derived from HFSE-enriched parental magmas, such as the fertile lithospheric mantle. Cenizas basaltic andesite is already enriched in some LILE, REE and HFSE with respect to the other mafic rocks in the Amazcala area (Figure 11), but still it shows the typical depletions in key elements of HFSE, such as Nb, as well as smaller contents of LILE and REE with respect to the peralkaline rocks of Amazcala (figures 8 and 9). Therefore, the LILE- and HFSE-rich nature of Amazcala comendites could be related to a pulse of fertile mantle that may have occurred locally at the Amazcala area. Eventually this enriched magma formed the magma chamber of Amazcala caldera at shallow depths (Figure 15), and while ascending the enriched magma became depleted in $\mathrm{Ba}, \mathrm{Sr}, \mathrm{P}$, and Ti by crystal fractionation of feldspar, apatite and Fe-Ti oxides and/or pyroxenes. Crystal fractionation increased from the earliest erupted phase, the EMP Plinian fallouts, to the caldera collapse event marked by the massive eruption of PDCs that formed Colón ignimbrite, to the last-erupted and most evolved phase, the rim lava domes rich in obsidian Extreme crystal fractionation and crustal assimilation processes of a magma originated within a continental rift setting to produce peralkaline rocks similar to those of the Amazcala caldera have been reported at the Kenya Rift (Leat et al., 1984; Macdonald et al., 1987, 2011; Macdonald, 2012), Trans-Pecos, Texas (White et al., 2006; Parker and White, 2008), the Gardar Province of Greenland (Macdonald et al., 2014), and the Gulf of California Rift (Vidal-Solano et al., 2005, 2008, 2013). Therefore, the Amazcala caldera comendites may have been related to a continental rift at the time range of 7.3 - 6.6 Ma in the Amazcala area.

\section{Conclusion}

Amazcala caldera, located at the central sector of the MVB, erupted at 7.3-6.6 Ma and produced peralkaline rhyolites, more precisely comendites, in the form of pre-caldera collapse widespread pumice-fallouts, syn-collapse ignimbrite-forming massive pyroclastic density currents, and post-collapse rim and central lava domes. Comendites of the Amazcala caldera could be explained by extreme crystal fractionation from an already enriched magma chamber in HFSE and REE. The extreme enrichment in the HFSE and the REE is difficult to explain by differentiation processes alone. $\mathrm{Nb}$ in particular is usually depleted in subduction-related magmas or in the melt formed during partial melting of the crust. Thus, the occurrence of HFSEand REE- rich rocks suggests that the source was already enriched in these elements. In this case, the most possible source is a fertile mantle in an intraplate-type setting. However, the Amazcala caldera lies within the central sector of the MVB, a subduction-related continental margin arc, and the Amazcala products occur between andesites and basalts with orogenic compositions depleted in $\mathrm{Nb}$ and other HFSE, and in REE, particularly the heavy REE. Amazcala caldera products chemically resemble more the Kenya Rift comendites and to extensional-related comendites of the western sector of the MVB, but there is not a clear evidence for a rift or a graben in the Amazcala caldera area. Instead, there are normal faults systems of regional extent, NNW- and ENE-oriented 
that were episodically active since their formation, probably from Miocene to present, and these faulting events could have been accompanied with volcanism. The comendite pulse of Amazcala may be related to an extensional episode at about $7.3-6.6 \mathrm{Ma}$ in this region. It is unknown if this probable extensional-related peralkaline magmatism was local or more widespread in the central sector of the MVB. With the available studies of the central MVB, the most common volcanic rocks have a compositional range of basalt to rhyolite, lacking this peralkaline signature. There are still several other silicic volcanic complexes in this sector of the MVB to be studied, which will determine if this type of magmatism was local for Amazcala caldera or if it can be considered a more regional event.

\section{Acknowledgements}

Manuscript was enriched and improved by comments and corrections of reviewers John Charles White and Jesús Roberto Vidal-Lozano, which we greatly appreciate. We thank Rufino Lozano-Santacruz for doing the FRX chemical analyses at the Instituto de Geología of Universidad Nacional Autónoma de México. Elizabeth Hernández and Elena Lounejeva provided help during the ICP-MS analyses. Financial support came from the Consejo Nacional de Ciencia y Tecnología (CONACYT), grant 33084-T, and Dirección General de Asuntos del Personal Académico of Universidad Nacional Autónoma de México (DGAPA-UNAM), grants PAPIIT-IN120999, PAPIIT-IN1 14606, and PAPIIT-IN104615.

\section{References}

Aguirre-Díaz, G.J., 1996, Volcanic stratigraphy of the Amealco caldera and vicinity, Central Mexican Volcanic Belt: Revista Mexicana de Ciencias Geológicas, 13(1), 10-51.
Aguirre-Díaz, G.J., 2001a, Recurrent magma mingling in successive ignimbrites from Amealco caldera, central Mexico: Bulletin of Volcanology, 63(4), 238-251.

Aguirre-Díaz, G.J., 2001b, Calderas of the central Mexican Volcanic Belt: Eos Transactions, 82(47), Abstract V32D-1020, F1350.

Aguirre-Díaz, G.J., 2008, Historia volcánica del entorno del valle de Querétaro, in Arzate-Flores, J., Cortés-Silva, A., LozanoGuzmán, A. (eds.), El Valle de Querétaro y su geoentorno: Querétaro, Mexico, Consejo Nacional de Ciencia y Tecnología del Estado de Querétaro, 23-40.

Aguirre-Díaz, G.J., Carranza-Castañeda, O., 2000a, Las grandes cuencas del OligoMioceno del centro de México: Geos, 20(3), 301.

Aguirre-Díaz, G.J. Carranza-Castañeda, O., 2000b, Oligo-Miocene basins of centralnorthern Mexico and the misinterpretation of their sedimentary fill as Quaternary alluvium, in 60th Annual Meeting of the Society of Vertebrate Paleontology: Mexico City, Mexico, Society of Vertebrate Paleontology, Abstracts of Papers, 25A.

Aguirre-Díaz, G.J., López-Martínez, M., 2000, La caldera de Apaseo, Guanajuato. Geología y geocronología de una nueva caldera en el sector central del Cinturón Volcánico Mexicano: Geos, 20(3), 308-309.

Aguirre-Díaz, G.J., López-Martínez, M., 2001, The Amazcala caldera, Querétaro, central Mexican Volcanic Belt. Geology and geochronology: Journal of Volcanology and Geothermal Research, 111, 203-218.

Aguirre-Díaz, G.J., López-Martínez, M., 2009, Geologic evolution of the DonguinyóHuichapan caldera complex, central Mexican Volcanic Belt, Mexico: Journal of Volcanology and Geothermal Research, 179(1-2), 133-148.

Aguirre-Díaz, G.J., Nelson, S. A., Ferrari, L., López-Martínez, M., 1997, Ignimbrites of 
the central Mexican Volcanic Belt, Amealco and Huichapan calderas (QuerétaroHidalgo), in Aguirre-Díaz, G.J., ArandaGómez, J.J., Carrasco-Núñez, G., Ferrari, L. (eds.), Magmatism and Tectonics of central and northwestern Mexico - A selection of the 1997 IAVCEI General Assemply excursions: Mexico City, Mexico, Universidad Nacional Autónoma de México, Instituto de Geología, $1-39$.

Aguirre-Díaz, G.J., Lozano-Santa Cruz, R., LópezMartínez, M., 1998, Geología y geoquímica del complejo volcánico Los Agustinos, Guanajuato (resumen), in Primera Reunión de Ciencias de la Tierra: Mexico City, Mexico, Instituto de Geología, Universidad Nacional Autónoma de México, 123.

Aguirre-Díaz, G.J., Carrasco-Hernández, J., López-Martínez, M., 1999, Nuevas calderas en el sector central del Cinturón Volcánico Mexicano: Geos, 19, 318.

Aguirre-Díaz, G.J., Zúñiga, R., Pacheco-Alvarado, F.J., Guzmán-Spezialle, M., Nieto-Obregón, J., 2000, El graben de Querétaro, México. Observaciones de fallamiento activo: Geos, 20(1), 2-7.

Aguirre-Díaz, G.J, Nieto-Obregón, J., Zúñiga, R., 2005, Seismogenic Basin and Range and intra-arc normal faulting in the central Mexican Volcanic Belt, Querétaro, México: Geological Journal, 40, 215-243.

Allan, J.F., Nelson, S.A., Luhr, J.F., Carmichael, I.S.E., Wopat, M., Wallace, P.J., 1991, Pliocene-Holocene rifting and associated volcanism in southwest Mexico: An exotic terrane in the making, in Daupin, J.P., Simoneit, B.R.T. (eds.), The Gulf and Peninsular Province of the Californias: American Association of Petroleum Geologists Memoir, 47, 421-445.

Barker, D.S., 1979, Cenozoic magmatism in the Trans-Pecos province: Relation to the Rio Grande Rift, in Riecker, R.E. (ed.), Rio Grande
Rift: Tectonics and Magmatism:Washington, D. C., U.S.A., American Geophysical Union, 382-392.

Bradshaw, T.K., 1992, The adaptation of Pearce element ratio diagrams to complex high silica systems: Contributions of Mineralogy and Petrology, 109(4), 450-458.

Cameron, K.L., Cameron, M., 1985, Rare earth element, ${ }^{87} \mathrm{Sr} /{ }^{86} \mathrm{Sr}$, and ${ }^{143} \mathrm{Nd} /{ }^{144} \mathrm{Nd}$ compositions of Cenozoic orogenic dacites from Baja California, northwestern Mexico, and adjacent west Texas: Evidence for the predominance of a subcrustal component: Contributions to Mineralogy and Petrology, 91(1), 1-11.

Capra, L., Macías, J.L., Garduño, V.H., 1997, The Zitácuaro volcanic complex, Michoacán, Mexico: Magmatic and eruptive history of a resurgent caldera: Geofisica Internacional, 36(3), 161-179.

Carmichael, I.S.E., Turner, F.J., Verhoogen, J., 1974, Igneous petrology: New York, U.S.A., McGraw-Hill, 739 p.

Carreón-Freyre, D., Cerca, M., Ochoa-González, G., Teatini, P., Zuñiga, F.R., 2016, Shearing along faults and stratigraphic joints controlled by land subsidence in the Valley of Queretaro, Mexico, in Galloway, D.L., Erkens, G., Kuniansky, E.L., Rowland, J.C., Land Subsidence Processes: Hydrogeology Journal, 24(3), 657-674.

Cerca-Martínez, L.M., Aguirre-Díaz, G.J., LópezMartínez, M., 2000, The geologic evolution of southern Sierra de Guanajuato, Mexico: A documented example of the transition from the Sierra Madre Occidental to the Mexican Volcanic Belt: International Geology Review, 42(2), 131-151.

Coney, P.J., Reynolds, S.J., 1977, Cordilleran Benioff zones: Nature, 270, 403-406.

Conrad, W.K., 1984, The mineralogy and petrology of compositionally zoned ash flow tuffs, and related silicic volcanic rocks, from 
the McDermitt caldera complex, NevadaOregon: Journal of Geophysical Research, Solid Earth, 89(B10), 8639-8664.

Demant, A., 1978, Características del Eje Neovolcánico Transmexicanoy sus problemas de interpretación: Revista Mexicana de Ciencias Geológicas, 2(2), 172-187.

Ferriz, H., Mahood, G.A., 1984, Eruption rates and compositional trends at Los Humeros volcanic center, Puebla, Mexico: Journal of Geophysical Research, Solid Earth, 89(B10), 8511-8524.

Garduño, V.H., Tibaldi, A., 1991, Kinematic evolution of the continental active triple junction of the western Mexican Volcanic Belt: Comptes Rendus de L'Académie des Sciences, 312(2), 135-142.

Gill, J., 1981, Orogenic andesites and plate tectonics: Berlin, Germany, Springer-Verlag, $390 \mathrm{p}$

Harrison, T.M., Watson, E.B., 1983, Kinetics of zircon dissolution and zirconium diffusion in granitic melts of variable water contents: Contributions to Mineralogy and Petrology, 84(1), 66-72.

Hernández, J., Carrasco-Núñez, G., Aguirre-Díaz, G.J., 2009, Dinámica eruptiva de la Pómez Ezequiel Montes en la caldera Amazcala, centro de México: Revista Mexicana de Ciencias Geológicas, 26(2), 482-500.

Hildreth, W., 1979, The Bishop Tuff. Evidence for the origin of compositional zonation in silicic magma chambers, in Chapin, C.E., Elston, W.E. (eds.), Ash-flow tuffs: Geological Society of America Special Paper, 180, 43-75.

Hildreth, W., Moorbath, S., 1988, Crustal contributions to arc magmatism in the Andes of Central Chile: Contributions to Mineralogy and Petrology, 98(4), 455-489.

Johnson, G.A., Harrison, G.G.A., 1990, Neotectonics in central Mexico: Physics of the Earth and Planetary Interiors, 64(2-4), 187-210.

Johnson, W.M., Maxwell, J.A., 1981, Rock and mineral analysis: New York, U.S.A., Wiley, $489 \mathrm{p}$.

Kowallis, B.J., Swisher III, C.C., CarranzaCastañeda, O., Miller, W.E., Tingey, D.G., 1998, Fission-track and single-crystal ${ }^{40} \mathrm{Ar}-$ ${ }^{39} \mathrm{Ar}$ laser-fusion ages from volcanic ash layers in fossil-bearing Pliocene sediments in central Mexico: Revista Mexicana de Ciencias Geológicas, 15(2), 157-160.

Lacan, P., Ortuño, M., Audin, L., Perea, H., Baize, S., Aguirre-Díaz, G., Zúñiga, F.R., 2018, Sedimentary evidence of historical and prehistorical earthquakes recorded along the Venta de Bravo Fault System, Acambay Graben (Central Mexico): Sedimentary Geology, 365, 62-77.

Langridge, R.M., Persaud, M., Zúñiga, F.R., Aguirre-Díaz, G.J., Villamor, P., Lacan, P., 2013, Preliminary paleoseismic results from the Pastores fault and its role in the seismic hazard of the Acambay graben, TransMexican Volcanic Belt, Mexico: Revista Mexicana de Ciencias Geológicas, 30(3), 463-481.

Le Bas, M.J., Le Maitre, R.W., Streckeisen, A., Zanettin, B., 1986, A chemical classification of volcanic rocks based on the Total AlkaliSilica system: Journal of Petrology, 27(3), 745-750.

Leat, P.T., McDonald, R., Smith, R.L., 1984, Geochemical evolution of the Menengai caldera volcano, Kenya: Journal of Geophysical Research, Solid Earth, 89(B10), 8571-8592.

Lipman, P.W., 1965, Chemical comparison of glassy and crystalline volcanic rocks: Washington, D.C., U.S.A., Geological Survey Bulletin, 1201-D, 24 p. 
Lozano-Santacruz, R., Bernal, J.P., 2005, Characterization of a new set of eight geochemical reference materials for XRF major and trace element analysis: Revista Mexicana de Ciencias Geológicas, 22(3), 329-344.

Luhr, J.F., 1997, Extensional tectonics and the diverse primitive volcanic rocks in the western Mexican Volcanic Belt: The Canadian Mineralogist, 35, 773-500.

Luhr, J.F., Nelson, S.A., Allan, J.F., Carmichael, I.S.E., 1985, Active rifting in southwestern Mexico: Manifestations of an incipient eastward spreading-ridge jump: Geology, 13(1), 54-57.

Macdonald, R., 1974, Nomenclature and petrochemistry of the peralkaline oversaturated extrusive rocks: Bulletin of Volcanology, 38(2), 498-516.

Macdonald, R., 2012, Evolution of peralkaline silicic complexes: Lessons from the extrusive rocks: Lithos, 152, 11-22.

Macdonald, R., Davies, G.R., Bliss, C.M., Leat, P.T., Bailey, D.K., Smith, R.L., 1987, Geochemistry of High-silica Peralkaline Rhyolites, Naivasha, Kenya Rift Valley: Journal of Petrology, 28(6), 979-1008.

Macdonald, R., Bagiński, B., Leat, P.T., White,J.C., Dzierżanowski, P., 2011, Mineral stability in peralkaline silicic rocks: Information from trachytes of the Menengai volcano, Kenya: Lithos, 125(1-2), 553-568.

Macdonald, R., Bagiński, B., Upton, B.G.J., 2014, The volcano-pluton interface: The Longonot (Kenya) and Kûngnât (Greenland) peralkaline complexes: Lithos, 196-197, 232-241.

McDowell, F.W., Clabaugh, S.E., 1979, Ignimbrites of the Sierra Madre Occidental and their relation to the tectonic history of western Mexico, in Chapin, C.E., Elston, W.E. (eds.), Ash-flow Tuffs: Geological Society of America Special Paper, 180, 113-124.

Mahood, G.A., 1980, Geological evolution of a Pleistocene rhyolitic center - Sierra La Primavera, Jalisco, Mexico: Journal of Volcanology and Geothermal Research, 8(24), 199-230.

Mahood, G.A., 1981, Chemical evolution of a Pleistocene rhyolitic center: Sierra La Primavera, Jalisco, Mexico: Contributions of Mineralogy and Petrology, 77(2), 129-149.

Mahood, G.A., Gilbert, C.M., Carmichael, I.S.E., 1985, Peralkaline and metaluminous mixed-liquid ignimbrites of the Guadalajara region, Mexico: Journal of Volcanology and Geothermal Research, 25(3-4), 259-271.

Milán, M., Yáñez, C., Navarro, I., Verma, S.P., Carrasco-Nuñez, G., 1993, Geología y geoquímica de elementos mayor de la caldera de Huichapan, Hidalgo, México: Geofísica Internacional, 32(2), 261-276.

Moore, G., Marone, C., Carmichael, I.S.E., Renne, P., 1994, Basaltic volcanism and extension near the intersection of the Sierra Madre volcanic province and the Mexican Volcanic Belt: Geological Society of America Bulletin, 106(3), 383-394.

Nelson, S.A., Carmichael, I.S.E., 1984, Pleistocene to Recent alkalic volcanism in the region of Sanganguey volcano, Nayarit, Mexico: Contributions of Mineralogy and Petrology, 85(4), 321-335.

Nelson, S.A., Hegre, J., 1990, Volcán Las Navajas: a Pliocene-Pleistocene trachyte-peralkaline rhyolite volcano in the northwestern Mexican volcanic belt: Bulletin of Volcanology, 52(3), 186-204. 
Nelson, S.A., Livieres, R.A., 1986, Contemporaneous calc-alkaline and alkaline volcanism at Sanganguey Volcano, Nayarit, Mexico: Geological Society of America Bulletin, 97(7), 798-808.

Nieto-Obregón, J., Aguirre-Díaz, G.J., LermoSamaniego,J.,Zúñiga, R., Pacheco, FJ., 2000, Structural framework of contemporaneous orthogonal active faulting in the northcentral sector of the Mexican Volcanic Belt, Queretaro, Mexico, in Geological Society of America Annual Meeting: Nevada, U.S.A., Geological Society of America, Abstracts with Programs, 32(7), 468.

Noble, D.C., 1970, Loss of sodium from crystallized comendite welded tuffs of the Miocene Grouse canyon member of the Belted Range tuff, Nevada: Geological Society of America Bulletin, 81(9), 2677-2688.

Ortuño, M., Zúñiga, R., Aguirre-Díaz, G.J., Carreón-Freyre, D., Cerca, M., Roverato, M., 2015, Holocene paleo-earthquakes recorded at the transfer zone of two major faults: the Pastores and Venta de Bravo faults (Trans-Mexican Volcanic Belt): Geosphere, 11(1), 160-184.

Parker, D.F., White, J.C., 2008, Large-scale silicic alkalic magmatism associated with the Buckhorn Caldera, Trans-Pecos Texas, USA: comparison with Pantelleria, Italy: Bulletin Volcanology, 70(3), 403-415.

Peccerillo, A., Taylor, S. R., 1976, Geochemistry of Eocene calc-alkaline volcanic rocks from the Kastamonu area, Northern Turkey: Contributions to Mineralogy and Petrology, 58(1), 63-81.

Pérez-Venzor, J.A., Aranda-Gómez, J.J., McDowell, F.W., Solorio-Munguía, J.G., 1996, Geología del Volcán Palo Huérfano, Guanajuato, México: Revista Mexicana de Ciencias Geológicas, 13(2), 174-187.

Pradal, E., Robin, C., 1994, Long lived magmatic phases at Los Azufres volcanic center, Mexico:
Journal of Volcanology and Geothermal Research, 63(3-4), 201-215.

Righter, K., Rosas-Elguera, J., 2001, Alkaline Lavas in the Volcanic Front of the Western Mexican Volcanic Belt: Geology and Petrology of the Ayutla and Tapalpa Volcanic Fields: Journal of Petrology, 42(12), 2333-2361.

Rock, N.M.S., 1987, The need for standardization of normalized multi-element diagrams in geochemistry: A comment: Geochemical Journal, 21(2), 75-84.

Rytuba, J.J., McKee, E.H., 1984, Peralkaline ash flow tuffs and calderas of the McDermitt Volcanic Field, Southeast Oregon and North Central Nevada: Journal of Geophysical Research, Solid Earth, 89(B10), 8616-8628.

Sánchez-Rubio, G., 1978, The Amealco caldera, in Geological Society of America Annual Meeting: New Orleans, U.S.A., Geological Society of America Abstracts with Programs, 10, 145.

Smith, R.L., Bailey, R.A., 1968, Resurgent cauldrons, in Coats, R.R., Hay R.L., Anderson C.A. (eds.), Studies in Volcanology: Colorado, U.S.A., Geological Society of America Memoir, 116, 613-662.

Suter, M., Carrillo-Martínez, M., López-Martínez, M., Farrar, E., 1995a, The Aljibes halfgraben - Active extension at the boundary between the trans-Mexican volcanic belt and the southern Basin and Range Province, Mexico: Geological Society of America Bulletin, 107(6), 627-641.

Suter, M., Quintero-Legorreta, O., LópezMartínez, M., Aguirre-Díaz, G., Farrar, E., 1995b, The Acambay graben: Active intraarc extension in the trans-Mexican volcanic belt, Mexico: Tectonics, 14(6), 1245-1262.

Suter, M., López-Martínez, M., QinteroLegorreta, O., Carrillo-Martínez, M., 2001, Quaternary intra-arc extension in the central Trans-Mexican volcanic belt: Geological Society of America Bulletin, 113(6), 693-703. 
Taylor, S.R., McLennan, S.M., 1985, The continental crust: Its composition and evolution: Oxford, U.K., Blackwell Scientific, $312 \mathrm{p}$.

Thompson, R.N., 1982, Magmatism of the British Tertiary Volcanic Province: Scottish Journal of Geology, 18, 49-107.

Thompson, R.N., Morrison, M.A., Dickin, A.P., Hendry, G.L., 1983, Continental flood basalts...Arachnids rule ok? in Hawkesworth, G.J., Norry, M.J. (eds.), Continental basalts and mantle xenoliths: Chesire, U.K., Shiva Publishing Limited, 158-185.

Valdez-Moreno, G., Aguirre-Díaz, G.J., LópezMartínez, M., 1998, El Volcán La Joya, estados de Querétaro y Guanajuato: un estrato volcán miocénico del Cinturón Volcánico Mexicano: Revista Mexicana de Ciencias Geológicas, 15(2), 181-197.

Verma, S.P., Carrasco-Núñez, G., 2003, Reappraisal of the geology and geochemistry of Volcán Zamorano, central Mexico: Implications for discriminating the Sierra Madre Occidental and Mexican Volcanic Belt provinces: International Geology Review, 45(8), 724-752.

Vidal-Solano, J.R., Paz-Moreno, F.A., Iriondo, A., Demant, A., Cochemé, J.J., 2005, Middle Miocene peralkaline ignimbrites in the Hermosillo region (Sonora, Mexico): Geodynamic implications: Comptes Rendus Geoscience, 337(16), 1421-1430.
Vidal-Solano, J.R., Lapierre, H., Stock, J.M., Demant, A., Paz-Moreno, F.A., Bosch, D., Brunet, P., Amortegui, A., 2008, Isotope geochemistry and petrogenesis of peralkaline Middle Miocene ignimbrites from central Sonora: relationship with continental breakup and the birth of the Gulf of California: Bulletin de la Société Géologique de France, 179(5), 453-464.

Vidal-Solano, J.R., Lozano-Santacruz, R., Zamora, O., Mendoza-Cordova, A., Stock, J.M., 2013, Geochemistry of the extensive peralkaline pyroclastic flow deposit of NW Mexico, based on conventional and handheld $\mathrm{X}$-ray fluorescence. Implications in a regional context: Journal of Iberian Geology, 39(1), 121-130.

White, J.C., Benker, S.C., Ren, M., Urbanczyk, K.M., Corrick, D.W., 2006, Petrogenesis and tectonic setting of the peralkaline Pine Canyon caldera, Trans-Pecos Texas, USA: Lithos, 91(1-4), 74-94.

White, J.C., Holt, G.S., Parker, D.F., Ren, M., 2003, Trace-element partitioning between alkali feldspar and peralkalic quartz trachyte to rhyolite magma. Part I: Systematics of trace-element partitioning: American Mineralogist, 88(2-3), 316-329.

Wilson, M., 1989, Igneous petrogenesis. A global tectonic approach: Dordrecht, The Netherlands, Springer, 466 p. 